\title{
Construction and destruction of some North American cratons
}

David B. Snyder

6 Geological Survey of Canada, Natural Resources Canada, 601 Booth Street, Ottawa, ON K1A 0E8 Canada

8

\section{Eugene Humphreys}

Department of Geological Sciences, University of Oregon, Eugene, OR 97403 USA

12

\section{Graham Pearson}

Department of Earth and Atmospheric Sciences, University of Alberta, Edmonton, AB Canada

14

16

18

10 Nov 2016

(c) 2016. This manuscript version is made available under the Elsevier user license http://www.elsevier.com/open-access/userlicense/1.0/ 
20 Abstract. Construction histories of Archean cratons remain poorly understood; their destruction is even less clear because of its rarity, but metasomatic weakening is an

22 essential precursor. By assembling geophysical and geochemical data in 3-D lithosphere models, a clearer understanding of the geometry of major structures within the Rae,

24 Slave and Wyoming cratons of central North America is now possible. Little evidence exists of subducted slab-like geometries similar to modern oceanic lithosphere in these construction histories. Underthrusting and wedging of proto-continental lithosphere is inferred from multiple dipping discontinuities, emphasizing the role of lateral accretion. Archean continental building blocks may resemble the modern lithosphere of oceanic plateau, but they better match the sort of refractory crust expected to have formed at Archean ocean spreading centres. Radiometric dating of mantle xenoliths provides estimates of rock types and ages at depth beneath sparse kimberlite occurrences, and these ages can be correlated to surface rocks. The 3.6-2.6 Ga Rae, Slave and Wyoming cratons stabilized during a granitic bloom at 2.61-2.55 Ga. This stabilization probably represents the final differentiation of early crust into a relatively homogeneous, uniformly thin (35-42 km), tonalite-trondhjemite-granodiorite crust with pyroxenite layers near the Moho atop depleted lithospheric mantle. Peak thermo-tectonic events at 1.86-1.7 Ga broadly metasomatized, mineralized and recrystallized mantle and lower crustal rocks, apparently making mantle peridotite more 'fertile' and more conductive by introducing or concentrating sulfides or graphite at $80-120 \mathrm{~km}$ depths. This metasomatism may have also weakened the lithosphere or made it more susceptible to tectonic or chemical erosion. Late Cretaceous flattening of Farallon lithosphere that included the Shatsky Rise conjugate appears to have weakened, eroded and displaced the base of the Wyoming craton below $140-160 \mathrm{~km}$. This process replaced the old refertilized continental mantle with relatively young depleted oceanic mantle.

\section{Introduction}

Deconstructing an object is often an excellent way to understand how it was built, but the construction, modification, destruction and reconstruction of the most ancient parts of the continents remain generally undetermined (Lee et al., 2011). Rocks forming parts of these cratonic nuclei of continents date back to the very early Earth and thus become entangled in debates about early Earth tectonics, particularly when plate tectonics as it is known today began. Here we will use examples from four relatively 
52 well-studied cratons in North America (Figure 1) to inform a more general review of how cratons formed and how their modification occurred throughout Earth history.

\subsection{Some Terms and Conditions}

Mutual understanding among authors and readers concerning specific, specialized word usage is important for clarity of concepts. Here we adopt the terminology in common usage throughout much of the diamond exploration industry in that cratons are long-lived stable blocks and Archean in age (Clifford's Rule: Clifford, 1966; Gurney et al., 2010; Shirey and Shigley, 2013). Long-stable lithosphere composed of amalgamated cratons, sutured together by Proterozoic orogens, typically with a considerable thickness of overlying sedimentary rocks is here termed a shield

62 (Hoffman, 1988, 2014; compare with composite craton of Aulbach et al., 2013) (Figure 1). By long-term stability we mean at least $1 \mathrm{Ga}$ since the last major tectonic disruption,

64 because origin mechanisms older than 1 Ga are debated (Eaton and Perry, 2013). Cratons generally have only thin sedimentary cover, implying modern surfaces that

66 have risen or always been near sea level. Archean cratons are also characterized by thick keels of melt-depleted mantle lithosphere (Boyd, 1989) which provides greater compositional buoyancy than that of most Proterozoic continental lithosphere. This buoyancy and the rheological stiffness due to the dry nature of depleted mantle are key factors in ensuring the survival of these ancient keels (Sleep, 2003; Jordan and Paulsen, 2013; Wang et al., 2014, 2015). Isolated from the convecting interior, the keels cool as the

72 thermal structure evolves toward an equilibrium where the reduced conductive heating of the thick lithosphere is balanced by radioactive heating (Michaut et al., 2009; Jaupart

74 et al., 2014). Cooling provides additional strength, results in the growth of a thermal boundary at the base of the depleted lithosphere (Cooper et al., 2004; Cooper and

76 Conrad, 2009; Lee et al., 2011), and increases net lithospheric density. The gross layering from depleted mantle to a basal thermal lithosphere to the convecting interior is 
78 supported by studies of xenolith composition (Rudnick et el., 1998; Kopylova et al., 1999) and texture (Kennedy et al., 2002), and by the continental-scale seismic imaging of upper mantle anisotropy (Yuan et al., 2011).

The plate tectonic paradigm explains much of what we understand about the

82 geology of the present day Earth. Subduction is the most important tectonic process operating today, but most geoscientists agree that it could not have operated in its

84 current fashion on the earliest Earth. The geologic time and manner in which early Earth geodynamics evolved to become modern plate tectonics remain major contentious 86 issues (e.g., Hamilton, 1998, 2015; Kamber, 2015). Systematic variations in combined hafnium and oxygen isotope ratios in zircons of different ages provide one estimate of 88 the relative proportions of reworked versus new crust (Dhuime et al., 2012). These variations indicate that $65 \%$ of the present-day volume of continental crust had formed 90 by $2.8 \mathrm{Ga}$ after which a sharp increase in the proportion recycled occurred. Before that time, the generation rate of new basaltic crust was nearly constant so that $\sim 73 \%$ of all 92 basaltic crust that was forming at $\sim 3.2$ Ga was juvenile. In contrast, only $20 \%$ of crust forming at $\sim 2.0 \mathrm{Ga}$ was juvenile, and today it approaches $0 \%$, implying all new basaltic

94 crust is currently composed of recycled crust (Dhuime et al., 2012; Spencer et al., 2014). Recycling basaltic crust with distinctive hafnium and oxygen isotope ratio signatures 96 requires sinking of some early crust in plastic or solid state through the underlying less dense mantle. We use this isotope evidence to infer that an increasing percentage of

98 basaltic crust that formed since 2.8 Ga was subducted in the solid state in order to be recycled, and thus assume that modern subduction-driven plate tectonics began at $2.8 \pm$

100 0.5 Ga (Roberts and Spencer, 2015), in agreement with the diamond inclusion record (Shirey and Richardson, 2011). Such chronology implies that oceanic crust did not 102 subduct before that time although crust did rejoin the mantle in a fluid state.

\subsection{Outstanding timescale issues}


We assume that the Archean was a time in Earth's history during which crust and mantle lithosphere differentiated but was not recycled deep into the mantle prior to 2.8 Ga (Solomatov and Stevenson, 1993). An inferred diachronous transition in convection state from sluggish lid (Sleep, 2009) to local down-welling of pyroxene-rich melts (Lee et al., 2011) to solid-state plate subduction probably occurred at 2.7-2.5 Ga (Table 1). With the initiation of plate tectonics, the uppermost solid-state surface layer was incorporated into convective downwellings for the first time. Early plate tectonics then began to recycle crust, volatiles and carbon which reset the ages of some mantle 112 rock (e.g., Pearson and Wittig, 2014).

Formation of oceanic lithospheric plates occurred within regions of divergent

114 flow because of enhanced differentiation and cooling. Such plates made possible the full development of modern plate tectonics as more wide-spread subduction of these plates

116 occurred during the Proterozoic. Subduction along the margins of cratons delivered volatiles into mantle beneath the cratons, volatiles that in turn rose to metasomatize

118 cratonic lower lithosphere. This introduced volatiles such as carbon into the lithosphere, now observable as regions of enhanced conductivity. Observations of intact lithospheric 120 plates of Archean or Proterozoic age within the mantle would demonstrate the onset of plate tectonics, but such observations remain inconclusive. Any slabs (Figure 3), or

122 older drips (Figure 2), not incorporated in the craton lithosphere have long since sunk completely through the mantle, therefore any evidence would need to come from the 124 structures within the craton itself (Bao and Eaton, 2015). Slab geometries defined seismically (e.g., Cook and Erdmer, 2005; Sigloch, 2011) can neither be traced directly to 126 dated outcrops nor constrained by accurate source location of representative xenoliths.

\subsection{Summary of assumptions}


The general tectonic history of cratons adopted here as background for describing specific North American examples is as follows:

Early (>2.7 Ga) proto-continental blocks roughly 100-km thick form above down-

132 welling instabilities in an early near-stagnant lid. Building blocks, large and small, collide and wedge into each other to form roughly $225-\mathrm{km}$ thick proto-cratons between

$134 \sim 3.0$ and 2.6 Ga (Cooper and Conrad, 2009); proximal extension and contraction accompanies this amalgamation.

136 The cratons develop a quasi-stable basal thermal boundary layer that is prone to convective instability, and its presence further isolates the overlaying mantle thermally

138 (Cooper et al., 2004; Lee et al., 2011). This additional cooling strengthens the craton.

The transition to modern-style plate tectonics begins at about $2.8 \mathrm{Ga}$ and Proterozoic 140 (2.0-1.8 Ga) subduction zones weld cratons into shields (e.g., the Siberian craton Rosen et al., 1994) and flux the lower lithosphere of cratons with carbon and water that 142 metasomatize them.

Flat-slab subduction and small-scale convective instabilities erode this metasomatically 144 weakened, lower lithosphere (Doin et al., 1997; Lenardic et al., 2003; Jaupart et al., 2007; Bao et al., 2014; Wang et al., 2015; Currie and van Wijk, 2016).

146 Isopycnicity keeps Archean cratons buoyant and near sea level (Jordan, 1978; Eaton and Perry, 2013) whereas Proterozoic shields are more susceptible to subsidence of tens of 148 kilometers.

\section{Methods}

Understanding lithospheric-scale tectonic processes requires information derived from depths across at least $50-700 \mathrm{~km}$ of the mantle. This depth range can only be 152 studied in situ today using geophysical techniques. Some methods provide spatially 
continuous or homogeneous coverage. Geochemical observations are available locally

154 and selectively where made possible by rare volcanic samples that include xenoliths or xenocrysts such as diamonds (including some from as deep as the upper-most lower

156 mantle; e.g., Harte et al., 1999; Stachel et al., 2005) and garnets, or where igneous rocks can be determined to have originated from mantle melts originating from great depths 158 (Mitchell, 2008; Tappe et al., 2013). Of most value to probing the lithospheric mantle are the xenoliths of peridotite and eclogite sampled by kimberlites and other small degree melts (Nixon, 1987). It is possible to obtain equilibration depth, bulk chemical composition and age from such samples (see review by Pearson et al., 2003). However,

162 occurrences of mantle xenoliths are small samples of large volumes of lithospheric mantle that provide "point-source" information. The challenge thus is to robustly

164 extrapolate the sparse geochemically derived knowledge across sometimes vast distances using geophysically derived knowledge.

\subsection{Seismology}

Three types of seismic data analyses are used in this review: teleseismic tomography, teleseismic receiver functions, and imaging using a controlled source. Seismic tomography provides a low-resolution, continental scale overview of mantle structures (e.g., Priestley and McKenzie, 2006; Schaeffer and Lebedev, 2014). Surface-, Sand P-wave velocity models provide increasingly better resolution because of the

172 inherent wavelength of the seismic wave used: 500-10000 km, 50-1000 km, and 10-80 km, respectively. However, source and receiver array shape and sparseness influence 174 the uniformity and specific resolution of anomalies in velocity more strongly than do seismic wavelength (Schmandt and Humphreys, 2010). Robust models to depths near 176 the $410 \mathrm{~km}$ discontinuity can be achieved with regional arrays. 
The other two methods depend on the conversion or reflection of seismic waves

178 at discontinuities in rock properties and thus provide relatively high-resolution definition of the structures causing these discontinuities. Resolution can be less than several kilometers, but becomes poorer with increasing depth (Miller and Eaton, 2010; Levander and Miller, 2012). For teleseismic arrivals, isolation of converted phases 182 generated at interfaces and timed against the direct arrival, enables estimation of discontinuity depth and contrast beneath the receiver station in what is traditionally

184 called receiver functions (Burdick and Langston, 1977; Bostock, 1998). Here P-to-S (Ps) conversions at multiple azimuths were used to estimate mantle structures in the remote 186 Slave and Rae cratons (Snyder et al., 2012).

The third method uses man-made seismic sources to map structures, primarily within the crust, but also in the uppermost mantle. Both reflected and refracted P-waves are used. The Lithoprobe SNORCLE survey crossed the southwest margin of the Slave craton and the adjacent Wopmay Orogen (Cook et al., 1999). The SAREX- Deep Probe surveys crossed the Wyoming craton (Henstock et al., 1998; Gorman et al., 2002) and the

192 CD-ROM survey interpreted structures across the Cheyenne Belt at the southern margin of the Wyoming craton (Henstock et al., 1998; Crosswhite and Humphreys,

194 2003; Karlson et al., 2005). The Lithoprobe Western Superior survey provides structural geometries within the crust of the Superior craton (White et al., 2003; Percival et al., 196 2006).

\subsection{Magnetotellurics}

Conductivity estimates for the entire cratonic lithosphere depend on high-quality magnetotelluric measurements (e.g., Chave and Jones 2012; Jones et al., 2014; Spratt et al., 2014). Recent surveys have enabled 3-D inversions of magnetotelluric observations to produce 3-D conductivity models of most parts of the Slave, Rae and Wyoming cratons (Snyder et al., 2014; Snyder et al., 2015; Megbel et al., 2014). Not all of these 
surveys use the same observational bandwidths. Recent Canadian surveys use

204 broadband sensors and recorders with a range of 0.01-1000 s (Spratt et al., 2014). Older Canadian surveys and USArray MT surveys used so-called long-period sensors and recorders with a range of 10- 10000 s (Jones et al., 2003; Meqbel et al., 2014). The latter surveys can sense conductors to $400 \mathrm{~km}$ where overlying lithosphere is relatively resistive, but suffer poorer sensitivity and resolution of conductors within the crust.

Xenolith suites that erupted in kimberlites and similar deeply derived magmatic 212 rocks provide the only physical samples of the lower crust and mantle lithosphere in the areas we consider. Fortunately, the Slave, Rae, Wyoming and Superior cratons have

214 all been subjected to intense diamond exploration over the past few decades, revealing several hundred kimberlites. Among these, less than a dozen locations provide mantle

216 xenolith suites that allow estimates of the mantle geotherm, measurements of bulk composition, and age estimation using isotopic methods. Estimates of the peridotite and 218 eruption age, degree of melt depletion, and metasomatic history exist for each craton. The Slave craton has three relatively extensive mantle xenolith suites (at the Jericho,

220 Diavik/Ekati and Gahcho Kué diamond mines). These cover a depth range of 40 to 210 km (Kopylova et al., 1999; Kopylova and Caro, 2004; Mather, 2013; Snyder et al., 2014).

222 The Rae craton has two locations discovered so far - Pelly Bay and Repulse Bay - that yield xenolith suites suitable for petrological/geochemical study. At both locations

224 samples are derived from limited depth ranges, but represent lower crust and the mantle at 90-150 km depths (Petts et al., 2014; Liu et al., 2015). The Wyoming craton has 226 two main xenolith sources, near the Colorado-Wyoming border (Kelsey Lake, Sloan and Leucite Hills sites) and in central Montana (Homestead, Williams and Bearpaw sites) with 70 to $200 \mathrm{~km}$ depths sampled (Carlson et al., 2004; Downes et al., 2004; Mirnejad and Bell, 2006; Schulze et al., 2008). 
It should be noted that the volcanic rocks that supplied this suite of mantle and deep-crustal samples erupted over a >500 Ma age range, from the early Cambrian (Pelly

232 Bay/Repulse Bay: Liu et al., 2015; Gahcho Kué: Kopylova and Caro, 2004) through the Jurassic (Jericho: Koylova et al., 1999; Heaman et al., 2006), to the Tertiary (Ekati/Diavik:

234 Lockhardt et al., 2004; Sarkar et al., 2015). Hence, the picture of the state of the lithosphere supplied by these xenolith suites can be displaced in time more than $500 \mathrm{Ma}$ 236 from the present-day geophysical observables.

\section{Building cratons}

\subsection{Ephemeral isopycnicity and survival}

A relatively constant freeboard of cratons has been used to argue for cratonic 240 construction in which the final phase of construction was cool (Flowers et al., 2004). The evolution of craton freeboard is affected by the buoyancy difference between ocean 242 and craton lithosphere, the fractional area of the Earth's surface occupied by continent, and the volume of ocean water. On billion-year time scales, the influences of a cooling

244 asthenosphere have a primary importance, both as a direct result of the cooling and indirectly because the oceanic crustal thickness diminishes as asthenosphere cools.

A $200-\mathrm{km}$ thick craton would have cooled by an average of about $250^{\circ} \mathrm{K}$. This amount of cooling assumes a $200^{\circ} \mathrm{K}$ cooling of the asthenosphere since the Archean, 248 current radioactive heating to be 35-40\% what it was in the Archean (e.g., Herzberg et al., 2010). For this calculation we reference the Priestley and McKenzie (2006) xenolith-

250 based geotherms from Jericho in the Slave craton and Udachanaya in the Siberia craton, and assume the current temperature at $50 \mathrm{~km}$ depth to be $200-250^{\circ} \mathrm{K}$ above that given

252 by a simple conductive geotherm. This cooling would have contracted the craton by 1.7 $\mathrm{km}$ (assuming all contraction to have occurred in the vertical direction, and using an 254 expansion coefficient of $\left.3.4 \times 10^{-4} /{ }^{\circ} \mathrm{K}\right)$. The corresponding average density increase is 28 
$\mathrm{kg} / \mathrm{m}^{3}$, which is minor $\left(6 \mathrm{~kg} / \mathrm{m}^{3}\right.$ more than that experienced by the asthenosphere) and 256 justifying an assumption of no horizontal flow.

A similar calculation for a $200-\mathrm{km}$ column of Earth beneath ocean lithosphere has 258 it contracting by $2.0 \mathrm{~km}$, assuming a thickening of average ocean lithosphere from 50 to $90 \mathrm{~km}$. Thus, thermal arguments alone predict $\sim 0.3 \mathrm{~km}$ of sea-level drop and also an 260 insignificant change in the craton buoyancy relative to the asthenosphere.

An evolution in the compositional buoyancy has also occurred. Assuming the 262 Archean ocean crust to be $20 \mathrm{~km}$ thick compared to a modern thickness of $6 \mathrm{~km}$, the ocean floor would lie $\sim 1.7 \mathrm{~km}$ above its current depth. Subsidence of $0.1 \mathrm{~km}$ is due to

264 decreased mantle depletion (assumed mantle density $=3300 \mathrm{~kg} / \mathrm{m}^{3}$, basalt density $=2920$ $\mathrm{kg} / \mathrm{m}^{3}$ ). These effects occur at relatively shallow depths and do not affect the

266 isopycnicity of the craton with respect to adjacent asthenosphere. The net sea-level drop calculated from the above thermal and compositional effects is $2 \mathrm{~km}$.

Note that the net load beneath the continent or ocean has not changed, only the density distribution. Thus no large-scale mantle flow occurs; a different density distribution can create pressure differences between the ocean and the continent, potentially driving flow within the upper $200 \mathrm{~km}$. Because we calculate little change in

272 the density difference between craton and ocean below $\sim 40 \mathrm{~km}$, the net effect is small and we ignore this effect. Also note that we have not considered the load of ocean water

274 although the volume change requires surface uplift or subsidence. If significant amounts of water can flow over (or drain from) the continent, this would be a change in 276 load; we ignore this relatively minor effect.

If freeboard remained about constant, then our calculations suggest that a sea278 level drop of $\sim 2 \mathrm{~km}$ would have been offset by a combination of: (1) an initially cool craton that warmed with time (Flowers et al., 2004), (2) continental growth, and (3) cratonic metasomatism. Significant densification by metasomatimism may have had a destabilizing effect on the craton, and may not have been possible. Recent 
282 geodynamical modeling suggests that the contrast in strength between cratonic lithosphere and the surrounding less depleted and hence weaker mantle is the key

284 factor for the longevity of cratonic keels, irrespective of their buoyancy (Wang et al., 2015). Finally, we note that since cratons are now isopycnic, they would have been 286 buoyant in the past (Eaton and Perry, 2013).

\subsection{Making early building blocks---drips and greenstones}

Does a consistent time frame exist for this craton building process across most cratons? Table 1 summarizes key dates known for the specific North American cratons reviewed here as well as for a few key global analogues. Most ages indicated are

292 concordant, but a few suggest early initiation in the Pilbara and Kaapvaal cratons (Van Kranendonk, 2010; Shirey and Richardson, 2011). The following time scale is inferred 294 from these ages.

A near-stagnant lid developed at 3.4-2.7 Ga (Figure 2a). Fractional crystallization 296 produced an olivine-rich mantle, pyroxene-rich lower crust and plagioclase-rich upper crust (Elkins-Tanton, 2012; Hamilton, 2015). With progressive lid cooling, near-stagnant

298 tectonics became organized but sluggish (Sizova et al., 2010; Crowley, in press). The lid cooled and thickened, and local down-welling initiated (Lee and Chin, 2014) (Figure

300 2b). The down-welling drove horizontal flow within the stagnant lid and hence necking or thinning of the lid distant from the down-welling site (Fig 2c). The thinning

302 enhanced mantle differentiation and resulted in a depleted, harzburgite-rich lowermost mantle lithosphere and formation of tonalite-trondhjemite-granodiorite (TTG) crust

304 (Bédard, 2006). Greenstone belts developed on many future cratons at 2.73-2.58 Ga (Table 1). Continued down-welling caused horizontal shortening above the site, and 306 thickening, uplift and erosion of crust resulted in turbidite basins being created by about 2.66 Ga (Figure 2c). By 2.64-2.58 Ga crust-mantle differentiation had progressed

308 sufficiently that dense pyroxene-rich lower crust also dripped into the mantle (Figure 
2d). Coeval peak metamorphic conditions melted the crust, and craton stabilization occurred in that the lithosphere structure to $180-210 \mathrm{~km}$ depths formed at that time and has survived to the present. Pyroxene-rich drips not trapped in the lithosphere would

312 not be observable as such today, having been recycled into the asthenosphere.

A presence of active and passive up-flowing mantle probably delivered volatile-

314 rich small-percentage melts to the base of the forming lithosphere (mechanical boundary layer of Tainton and McKenzie, 1994; Aulbach, 2012). These melts perhaps enhanced melting of the pyroxene-rich layer (Figure 2d), furthered differentiation, and promoted upward migration of more felsic components to the near surface to form TTG

318 crust (Bédard and Harris, 2014). The result was a layered lithosphere about 120-km thick, similar to oceanic plateaus such as Ontong-Java today (Figure 3) (Ishikawa et al., 320 2011; Tommasi and Ishikawa, 2014). Some of these blocks accreted above zones of downwelling to form composite proto-cratons 200-250 km thick (Figure 3) (Snyder et 322 al., 2014).

The products of this sequence are preserved on all cratons, with similar ages in 324 all but a few cases (Table 1). Various cratons do preserve different fractions of each component: TTG-basement, greenstones, late granites, turbidite basins. Below we focus 326 specifically on examples from the main North American cratons.

\section{Constructing the cratons---tectonic wedging of peers}

3284.1 Slave craton construction

\subsubsection{Crustal geology}

The exposed Archean crust of the Slave craton is $500 \mathrm{~km}$ by $700 \mathrm{~km}$, surrounded by Paleoproterozoic or younger orogens (Figure 4). An ancient gneiss complex (Central Slave

332 Basement Complex of Bleeker et al. 1999) in the west hosts some of the oldest rocks on Earth, 4.04-2.83 Ga gneiss and granitoid rocks, that are overlain by the 2.8 Ga Central Slave 
334 Cover Sequence of quartzite and banded iron formation (Table 1) (Bleeker, 2002). This complex comprises large antiforms overlain or flanked by 2.73-2.58 Ga basalt-dominated greenstones and 2.67 Ga turbiditic sedimentary belts of the Yellowknife Supergroup (Bleeker, 2003). The supracrustal and granitoid rocks are deformed by several discrete, intersecting fold sets to form an archetypical Archean "granite-greenstone terrain". The oldest major folds trend NE-SW and, at 2.645-2.635 Ga, precede the abundant 2.635-2.605

340 Ga tonalite-granodiroite plutons of the Defeat and Concession Suites (Davis et al., 2003; Table 1). The more evolved two-mica granites of the 2.59-2.58 Ga Prosperous Suite are coeval with peak metamorphism and craton-wide folding along N- to NW-trending axes (Davis and Bleeker, 1999). Gold deposits formed in the near-surface about 2.60-2.59 Ga 344 (Siddorn et al., 2006). The associated high heat flux and craton-wide nature of this latter event appear to have been the last major phase of tectono-thermal activity before the crust and mantle experienced a long period of quiescence (Bleeker, 2002). Isotopic studies of large intrusive bodies show $\mathrm{Nd}$ and $\mathrm{Pb}$ isotope compositions that define a rough northsouth trend in age; the 4.04-2.83 Ga ancient nucleus of the Central Slave Basement Complex (Bleeker et al. 1999) lies to the west, whereas isotopically juvenile basement rocks 350 lie to the east (Davis et al., 2003).

Following the last major phase of tectono-thermal activity at $2.58 \mathrm{Ga}$, Slave crust was 352 gradually exhumed until $2.00 \mathrm{Ga}$ by $10-15 \mathrm{~km}$ of slow uplift and erosion as evidenced by Paleoproterozoic cover sequences that unconformably overlie neighboring Archean

354 basement (Hoffman, 1980). Sediment-rich Paleoproterozoic sequences such as the Coronation Supergroup on the western margin of the craton probably formed on a passive margin. Numerous mafic dyke swarms within the craton may date rifting at 2.23-2.00 Ga (Bleeker, 2003). Regionally reconstructed oblique convergence of the Slave and Rae cratons 358 during the Paleoproterozoic (2.0-1.8 Ga) assembly of NUNA (Hoffman, 2014) is consistent with the evolution of local structures observed along the southern margin of the Slave 360 craton, e.g., the Great Slave Lake shear zone (Figure 4) (Hanmer et al., 1992). This common 
boundary with the Rae craton is defined by the contact between Slave craton granitoids with granitoids and ortho- and para-gneisses of the Taltson and Thelon magmatic tectonic zone.

\subsubsection{Mantle structure}

The inferred Archean mantle of the Slave craton at $100 \mathrm{~km}$ depth extends laterally over $800 \mathrm{~km}$ by $1200 \mathrm{~km}$ (Figure 1). An ENE-WSW striking zonation within the mantle was first identified using population statistics of individual garnet crystals recovered from surface till samples taken downstream of glacier ice flow from kimberlites (Grütter et al., 1999). Geochemical analysis of these crystals revealed a zone of anomalously high concentrations of G10 garnets centered roughly on the Lac de Gras area where independent

372 geochemical observations identified an ultra-depleted, olivine-rich layer at 70-145 km depth separated from a deeper, metasomatically re-enriched (reduced) layer by an

374 unusually sharp transition (Griffin et al., 1999; Aulbach, 2012). Magnetotelluric observations indicated a prominent conductor at $80-100 \mathrm{~km}$ depths also centered on the 376 Lac de Gras region (Jones et al., 2003). Structural and geochemical analyses of xenoliths from kimberlites indicate different depths for the base of the lithosphere at the time of

378 kimberlite eruption (Kopylova and Caro, 2004). Estimates range from $214 \pm 15 \mathrm{~km}$ in the north to $236 \pm 6 \mathrm{~km}$ in the south (Mather et al., 2011), but it must be kept in mind that these estimates are made from kimberlites of disparate eruption ages and so small variations in depth could reflect the erosive effects of small-scale convective instabilities on the base of 382 the lithosphere (Cooper and Conrad, 2009).

Three major mantle lithosphere discontinuity surfaces within the Slave craton have 384 been mapped using multi-azimuthal receiver functions. The Moho at depths of $39 \pm 4 \mathrm{~km}$ and mid-lithosphere discontinuities at depths of 140-155 km appear relatively flat regionally (Figure 5) (Snyder et al., 2014). A feature at 80-110 km depths found beneath the Lac de Gras kimberlite field, may connect to the west with underthrust lithospheric slabs 
388 associated with the Hottah terrane within the Wopmay Orogen (Ootes et al., 2015). Because the mid-lithosphere discontinuity appears primarily on the transverse component of multiazimuthal receiver functions, its implied seismic anisotropic behaviour will produce polarity flips at back azimuths coinciding with fast polarization directions (e.g., Wirth and Long, 2014). This characteristic makes changes in properties of the over- and underlying layers easier to observe than if only subtle changes in compositions caused the discontinuity. Within the southeast Slave craton such changes in discontinuity polarity are observed from northwest to southeast (Snyder et al., 2014). A polarity flip between the Diavik and Gacho Kué diamond mines correlates both with where xenocrysts from kimberlites show increasing eclogite/peridotite protolith ratios and where the boundary with the more juvenile eastern terrane expressed at crustal levels (Figure 6) (Snyder and Grütter, 2010; Helmsteadt and Pehrsson, 2012; Kopylova et al., 2016). In contrast, no polarity flip is observed along a profile between Diavik and the Snap Lake diamond mine, indicating that the uppermost mantle beneath both these locations is probably associated 402 with the ancient Central Slave Basement Complex (Figure 4).

Comparison of diverse data sets for the Slave craton reveals that this mid404 lithospheric discontinuity coincides with a vertical gradient in surface wave velocity, a relatively sharp change in seismic anisotropy, and with changes in rock types (harzburgite 406 dominated to lherzolite dominated) as determined from xenoliths and xenocrysts (Figure 6) (Snyder et al., 2014). The 'Lac de Gras' discontinuity dips to the southeast between 85 and $110 \mathrm{~km}$ depths and lies 20-30 km deeper than the top of the broader zone of enhanced conductivity (Figure 7). Beneath the westernmost Slave craton, a subsidiary mantle discontinuity associated with the mapped Hottah terrane dips northeast, whereas the main western discontinuity surface dips eastward. Beneath Yellowknife, the Hottah surface is at

$41270 \mathrm{~km}$ depth and coincides with the top of Bostock's (1998) anisotropic $( \pm 5 \%) \mathrm{H}$ discontinuity, which was interpreted as a 10-km-thick subducted oceanic crust. The main 414 surface coincides with Bostock's (1998) X discontinuity at $135 \mathrm{~km}$ depth. Cook and Erdmer 
(2005) used seismic reflection profiling to interpret the $\mathrm{H}$ discontinuity as separating a

416

418

420

422

424

426

428

wedge-shaped westernmost Slave lithosphere from the over- and underthust Hottah

terrane. The same authors propose that the $X$ discontinuity separates a wedge of Hottah terrane from subducted Proterozoic Ft. Simpson oceanic lithosphere (Figure 6).

Re-Os isotopic dating of central Slave craton mantle xenoliths and xenocrysts suggests the presence of some depleted ancient (ca. 3.1 Ga) harzburgite (Irvine et al., 2003; Aulbach et al., 2013), but a much greater abundance of 2.75 Ga peridotites (Heaman and Pearson, 2010; Mather, 2013). To the north, spinel peridotites are the oldest (ca. 2.9 Ga) xenoliths and lithosphere age decreases with depth; subducted eclogite (2.2-2.0 Ga) and ages of 1.8 and $1.3 \mathrm{Ga}$ are interpreted as due to mantle metasomatism related to the Wopmay orogen and Mackenzie igneous event, respectively (Schmidberger et al., 2007; Heaman et al., 2006; Heaman and Pearson, 2010; Kopylova et al., 2016). More recent passage of subducted slabs beneath the base of the craton may also have induced metasomatism and diamond formation (Weiss et al., 2015). Changes in fabric orientation across seismic discontinuities and velocity gradients at 140-150 km depths suggested two ancient layers of peridotite with distinct uniform fabrics (Figure 6) (Snyder et al., 2014), whereas conductivity (Jones et al., 2003) and rare earth element trends (Aulbach et al., 2013) support overprinting of the layered structures by several phases of metasomatism.

\subsubsection{Summary}

Available isotope dates indicate that the oldest Slave lithosphere (both crust and mantle) has a consistent age (>2.75 Ga) to depths of $100-140 \mathrm{~km}$. In the south and east, a more juvenile Archean terrane was wedged on top of and below the more ancient block. In the north and west, metamorphism or metasomatism has overprinted the mantle below 100 $\mathrm{km}$ with younger isotopic signatures, including partial replacement by Palaeoproterozoic lithosphere to $250 \mathrm{~km}$ depth (Figure 6). Everywhere deep within the central Slave craton, 
reducing channelized metasomastism by melts has locally refertilized peridotite, enhancing

442 conductivity and diamond prospectivity.

\section{$444 \quad 4.2$ Rae craton construction}

\subsubsection{Crustal geology}

Exposed Archean crust of the Rae craton is recognized about $2000 \mathrm{~km}$ along its primary southwest-northeast axis, with a circa $750 \mathrm{~km}$ breadth (Figure 8). The craton

448 has a number of component blocks: Committee Bay, Repulse Bay, central Baffin, Queen Maud, SW Rae, Chesterfield and Cumberland (Hoffman, 1988; St-Onge et al., 2006;

450 Berman et al., 2007, 2013; Eglington et al., 2013). Relatively juvenile Archean crust with 2.74-2.69 Ga komatiite-quartzite sequences (Committee Bay, Woodburn Lake, Eqe Bay

452 greenstones) distinguishes the central part (Sanborn-Barrie et al., 2014). Major adjacent crustal terranes including Hearne, Meta Incognita, and Sugluk are here considered

454 lesser terranes that have Archean crust but $<150 \mathrm{~km}$ of lithospheric thickness (Snyder et al., 2012, 2015).

The central Rae craton is characterized by Neoarchean, amphibolite to granulitegrade, tonalitic to granitic orthogneisses as well as the distinctive northeast-striking

458 2.730-2.687 Ga komatiite-bearing greenstone belts (Skulski et al., 2003; Sanborn-Barrie et al., 2014). These rocks are intruded by $2.72-2.68 \mathrm{Ga}$ tonalite and voluminous $2.63-2.58$

460 Ga monzogranitic plutons (Hinchey et al., 2011 and references therein); Nd model ages of 2.87-2.52 Ga suggest predominantly juvenile isotopic source regions for these crustal 462 rocks (Peterson et al., 2010). These plutons are recognized from northwestern Saskatchewan as far east as the Melville Peninsula (LaFlamme et al., 2014) and mark 464 Rae craton stabilization (Berman et al., 2013).

The more ancient Repulse Bay block includes the Melville Peninsula and 466 Southampton Island (Figure 8) and is characterized by 2.97 Ga volcanic and 
metasedimentary rocks of the Prince Albert greenstone belt, intruded by 2.63-2.58 Ga

468 monzogranitic plutons (LaFlamme et al., 2014). The plutons are locally metamorphosed to amphibolite or granulite grade and have 3.63-2.84 Ga Nd model ages. Igneous cores

470 of zircon crystals from lower crust xenoliths have ages of 3.5-2.8 Ga (Petts et al., 2014; Eglington et al., 2013). The Repulse Bay block is separated from the Committee Bay

472 block by a set of cryptic structures that include ancient northeast-southwest trending, steeply dipping structures (Sanborn-Barrie et al., 2014) that are apparently offset by

474 neotectonic faults such as the Wager Bay shear zone (Snyder et al., 2015).

The Chesterfield block of the Rae craton (Berman et al., 2013) and central Hearne

476 domain appear distinct from each other because of isotopically juvenile, 2.7 Ga mafic to intermediate volcanic rocks of the central Hearne supracrustal belt that are cut by 2.66

478 Ga granitic plutons associated with a regional metamorphic event (Davis et al., 2006). The Hearne domain lacks any Archean magmatic or tectonic activity after 2.66 Ga. The 480 Chesterfield block has 2.7 Ga supracrustal rocks and tonalite plutons. The block is intruded by 2.6 Ga granitic plutons (Davis et al., 2006) that tie it to the Rae craton after 482 its ca. 2.64 Ga accretion (Berman et al., 2007). The Chesterfield fault zone separates the Chesterfield block from the Committee Bay and Repulse Bay blocks (Figure 8). The fault 484 reactivated during the 2.56-2.50 Ga MacQuoid orogeny (Hanmer et al., 2006; Berman et al., 2013) and again when microcontinents accreted to the southeastern flank of the Rae 486 craton at 1.9-1.87 Ga, the latter collectively designated as the Snowbird phase of the Hudsonian orogeny (Berman et al., 2007). The Chesterfield fault zone is a northwest488 vergent thrust that juxtaposes $~ 10$ kbar granulite facies rocks with 1.9 Ga hornblende cooling ages in the hanging wall against $\sim 4 \mathrm{kbar}$, lower amphibolite-facies rocks with 490 1.8 Ga cooling ages in the footwall (Berman et al., 2013; Pehrsson et al., 2013). Amphibolite-grade remnants of 2.1-1.9 Ga Paleoproterozoic sedimentary cover occur throughout the central Rae craton (Rainbird et al., 2010). 


\subsubsection{Mantle structure}

Mantle xenolith samples are currently only available from two locations, one in each of the Repulse Bay and Committee Bay blocks (Figure 8). Based on PGE patterns and Os model ages, the peridotites from both localities can be categorized into three age groups. Archean ages of 2.8-2.6 Ga characterize Committee Bay mantle and 3.0-2.7 Ga Repulse Bay mantle (Liu et al., 2015). Paleoproterozoic ages of 2.1-1.7 Ga are observed from both locations, as are "Recent" (<1 Ga) model ages that are similar to the ca. 546 Ma kimberlite eruption age. As within the Slave craton, the Archean ages indicate that depleted Archean lithospheric mantle formed coevally with the overlying Archean crustal basement. The subtle difference in Os model ages between Committee Bay and Repulse Bay correlates with the age difference between overlying crustal basement and with assembly by collision of separate Archean blocks at 2.7-2.6 Ga.

Rae craton peridotite xenoliths have been variably altered by serpentinization, silicification and carbonation. Nonetheless, their high absolute PGE concentrations, mantle-like melt-depleted PGE patterns and low bulk rock $\mathrm{Al}_{2} \mathrm{O}_{3}$ contents indicate that

508 these secondary processes, as well as mantle metasomatism recorded in pristine silicate minerals, did not significantly modify the relative compositions (Liu et al., 2015). The observed depletion in $\mathrm{Pd}$ and $\mathrm{Pt}$, bulk $\mathrm{Al}_{2} \mathrm{O}_{3}$ contents of less than $1.5 \%$ as well as the depleted compositions of the silicate and oxide minerals all indicate that the peridotites

512 are residues of considerable melt depletion. One group of peridotites clearly indicate extensive melt depletion in the Neoarchean. Re-PGE characteristics of the

514 Paleoproterozoic age group can be interpreted as recording primary melt depletion, but at lower extents of melting than occurred within the Archean age group. Re-PGE characteristics are not consistent with Paleoproterozoic ages reset by melt refertilization of the Archean peridotites because higher Re enrichments would be expected (Liu et al., 2015). These Paleoproterozoic melt depletion ages may represent juvenile lithospheric 
mantle that partially replaced lower portions of Archean lithospheric mantle (Liu et al., 2015) during the 1.77-1.70 Ga Nueltin event (Table 1) (Petersen et al. 2002).

The vertical distribution of the three age clusters in the central Rae lithospheric

522

524

526

mantle is consistent with the observation of seismic lithospheric discontinuities (Snyder et al., 2012, 2015) that indicate two or more layers of fossil lithospheric mantle fabric beneath the central Rae craton. Seismic discontinuities from multi-azimuthal receiver functions map gently dipping discontinuities that project upward into major linear zones of deformation (Snyder et al., 2015). Most deformations are Paleoproterozoic (1.8 Ga), but some rocks also record older deformation (Sanborn-Barrie, et al., 2014). The southeastward dip of the most prominent discontinuities indicate that lesser or more juvenile continental blocks such as the Hearne, Sugluk and Meta-Incognita were thrust northwestward onto the flank of the central Rae craton (Figures 9 and 10), reaching their current position following major horizontal shortening strain associated with the Trans-Hudson Orogeny (St-Onge et al., 2006). A shallow mantle lithosphere layer with predominately Archean depletion ages underlain by a layer of mixed Archean and

Paleoproterozoic ages is indicated by joint interpretation of geophysical, geological and geochronological observations. Post-melting metasomatic enrichment is clearly indicated by complex zoning within garnets and sinuous garnet REE patterns (Liu et al., 2015) that may have generated the enhanced conductivity regions evident throughout the central Slave mantle at 100-200 km depths.

\subsubsection{Summary}

Within its central part, the Rae craton grew by successive accretion of terranes around an ancient nucleus that is today represented by the Repulse Bay block. Note that we do not here discuss the southern or northern parts of the rae craton due to limited data and observations. Accretion added the Committee Bay block by $2.7 \mathrm{Ga}$, the Chesterfield block by $2.64 \mathrm{Ga}$, the Hearne and other inter-Superior blocks by $1.9 \mathrm{Ga}$. 
Proterozoic alterations included the possible replacement of the lower $(100-200 \mathrm{~km})$

546 lithosphere along gently east-dipping discontinuities and the metasomatism that enhanced conductivity at depths greater than $100 \mathrm{~km}$.

\subsection{Wyoming craton construction}

\subsubsection{Crustal geology}

The exposed Archean basement rocks associated with the Wyoming craton occur within an area 700 by $500 \mathrm{~km}$ (Figure 11, Kilian et al., 2016). The oldest rocks come from

552 its northern Bighorn block where 3.5-3.1 Ga tonalitic-granitic gneisses occur in and near the Beartooth Mountains (Mueller and Frost, 2006; Krogh et al., 2011). Isotopic evidence 554 indicates that an ancient nucleus block with components $>3.0$ Ga lies between the Great Falls tectonic zone and Laramie Mountains (Chamberlain et al., 2003). Magmatism at

556 2.9-2.75 Ga produced tonalite-trondjemite plutons which evolved to high-potassium granites (Barker et al., 1979; Frost et al., 2006). The 3.30 Ga Sacawee Orthogneiss of this

558 ancient northern TTG block is capped by the 2.85 Ga Barlow Gap cover sequence (quartzite, pelitic schist, iron formation) (Table 1). The Bighorn block is bounded by the

560 Oregon Trail structure at its southern margin, and suffered little internal tectonism or magmatism after $2.75 \mathrm{Ga}$, with the exception of the 2.705 Ga Stillwater complex

562 intrusion, (Chamberlain et al., 2003; Grace et al., 2006). Three discrete pulses of magmatism occurred in the southern Sierra Madre part of the craton at 2.72-2.67, 2.63-

5642.60 , and 2.55-2.50 Ga; the pulses were interpreted as evidence of an accretionary margin (Frost et al., 1998). Three periods of greenstone basin development indicates

566 that southward-migrating tectonism preceded each pluton bloom by 20-40 Ma; a large percentage of these greenstone belts contain meta-turbidites, but no komatiites

568 (Houston et al., 1993). 
Deformation is strongest along the northwestern and southern margins of the 570 Wyoming craton (Figure 11). In the northwest, shear zones are dated at 2.56-2.45 Ga (Mogk et al., 1992). In the south, generally north-vergent thrusting occurred at 2.83, $572 \quad 2.70-2.67$ and 2.62 Ga within the diffuse Oregon Trail structure (Figure 11). This structure separates the >2.7 Ga Sierra Madre block from the more ancient Bighorn block 574 across a $<2.65$ Ga south-dipping crustal accretion zone (Chamberlain et al., 2003; Grace et al., 2006). Rock ages throughout this Sierra Madre block and eastward to the Black 576 Hills (Figure 11) are predominantly Proterozoic (2.0-1.5 Ga) and therefore this block is not considered part of the Wyoming craton (Kilian et al., 2016). These Proterozoic ages

578 date the docking of the Yavapai terrane along the 1.78-1.62 Ga Cheyenne Belt. The southern Wyoming craton was also modified by two periods of extension and mafic 580 dyke swarm intrusion at 2.1-20 and 1.5-1.4 Ga (Snyder et al., 1990), that resulted in crust thinner by $5-10 \mathrm{~km}$ beneath the Sierra Madre block (Figure 12) (Gorman et al., 582 2002). In the north, the Great Falls tectonic zone was active at $1.85 \mathrm{Ga}$; the docking of the Medicine Hat block occurred at 1.76-1.72 Ga, and was coeval with final closure of eastern Wyoming and Superior cratons along the Dakotan orogen (Chamberlain et al., 2003; Kilian et al., 2016).

Seismic surveys indicate that unusually fast seismic wave speeds characterize the lower crust of the Wyoming craton and neighboring Medicine Hat block (Gorman et al., 2002). This layer is not found beneath upper crust younger than $2.75 \mathrm{Ga}$. Lower crustal xenoliths from the Medicine Hat block have 1.8-1.7 Ga ages (Davis et al., 1995), coeval with deformation along the Great Falls tectonic zone. Few xenoliths directly sample the lower crust within the Wyoming craton so these fast wave speeds may be speculated to 592 derive from a pyroxenite-rich layer inherited from crust formation that was perhaps enhanced by mafic intrusions associated with the $2.705 \mathrm{Ga}$ Stillwater complex that 594 intruded shallower in the crust. 


\subsubsection{Mantle structure}

Several xenolith suites help constrain the composition and history of mantle associated with the Wyoming craton (Figures 11 and 12). Homestead suite peridotites from $110-150 \mathrm{~km}$ depths represent the only clear sampling of the Wyoming craton mantle, and define a geotherm $\left(60 \mathrm{mWm}^{-2}\right.$ : Irving et al., 2003) that is significantly hotter than geotherms typical of cratonic mantle. The peridotite suite is $92 \%$ harzburgites with some G10 garnets and veins of clinopyroxene, websterite and phlogopite (Carlson et al., 2004). Peridotites from the Homestead kimberlite appear to have experienced melt depletion in the Archean (2.7-2.5 Ga TRD ages), with some samples recording isotopic evidence of metasomatic modification in Palaeo- to Mesoproterozoic times (Carlson et al., 2004). The nearby Williams peridotite xenolith suite erupted near the Great Falls tectonic zone (Figure 11). Although their Re-Os isotope systematics are complex, 'low temperature' xenoliths from 100-140 km depth have Re-depletion ages of 2.5-1.7 Ga indicative of a common Archean melt depletion history followed by Mesoproterozoic modification (Carlson et al., 1999). A 130-170 km deep 'high temperature' suite produces temperatures similar to those found at Homestead (Carter, 2004), but they yield Re-Os ages of <200 Ma (Carlson et al., 1999, 2004). Farther north and within the Medicine Hat block, the Bearpaw suite has Proterozoic (1.8-1.2 Ga Sm-Nd and Lu-Hf model ages) phlogopite-rich websterites, interpreted to represent metasomatism of the cratonic root (Downes et al., 2004). The Kelsey Lake and Sloan peridotite suites erupted $\sim 600 \mathrm{~km}$ to the south, near the Cheyenne Belt (Figure 11). The Kelsey Lake mantle suite has Archean harzburgites with peridotitic diamonds typical of cratonic keels (Schulze et al., 2008). The Sloan mantle suite shows combined Nd-Hf-Os isotopic evidence of having been formed by melt depletion in the Mesoproterozoic (Carlson et al., 2004). The Sloan mantle suite also has eclogites and Fe-rich Proterozoic peridotites, typical of sutures and that appear to confirm (Schultze et al., 2008) an earlier model of a 
622 southward dipping boundary between depleted Archean peridotite and overlying enriched Proterozoic peridotites with websterite veins (Eggler et al., 1988). The Leucite

624 Hills suite from within the Sierra Madre block has 2.8 Ga depleted peridotites that were extensively metasomatized at $>1 \mathrm{Ga}$ by veins of phlogopite, richterite and

626 clinopyroxene (Mirnejad and Bell, 2006).

The regional controlled-source seismic surveys SAREX, Deep-Profile and CD-

628 ROM (Figure 11) revealed dipping seismic continuities within the crust and uppermost mantle (Henstock et al., 1998; Gorman et al., 2002; Karlstrom et al., 2005). Within the

630 crust, seismic discontinuities are interpreted to dip away from the Wyoming craton as part of tectonic wedges whereas within the mantle, discontinuities dip beneath the

632 craton. The overall geometry is of a tectonic wedge with its tip near the Moho. This conflicts with the xenolith interpretations because isotopic constraints from mantle 634 xenoliths from the Kelsey Lake and Sloan kimberlites indicate a Proterozoic over Archean southward dipping boundary (Eggler et al., 1988) at the time of their eruption 636 in the Devonian (Figure 12). As will be discussed further, this apparent relationship in the mantle may have been reversed in the Tertiary. Recent teleseismic and magnetotelluric studies using USArray data provide deeper structural information within the upper mantle. Common conversion point 640 stacking of Ps and Sp phases provide regionally consistent estimates of Moho depth and laterally consistent phases that indicate velocity decreases with depth at 75 and $125 \mathrm{~km}$

642 (Figure 13E and F) (Levander and Miller, 2012; Hopper et al., 2014). These deeper discontinuities were interpreted as the base of the lithosphere by the authors, but 644 probably represent intra- or mid-lithosphere discontinuities related to mantle layering (Figure 12). Steeply dipping structures inferred from strong conductors associated with 646 the Great Falls tectonic zone dip northwestward to about $80 \mathrm{~km}$ depth (Meqbel et al., 2014) (Figure 13D), a geometry consistent with an extensive, undeformed Wyoming 648 craton keel such as characterized by depleted harzburgite xenoliths found at the 
Williams and Homestead locales (Figure 12). Structure beneath the Cheyenne Belt is

650 complex and possibly results from a southward-pointing crustal wedge above a northward-pointing mantle wedge (Karlstrom et al., 2005). Magnetotelluric conductors

652 are consistent with a very steeply southeast dipping shear zone to about $200 \mathrm{~km}$ depth (Figure 13D).

$654 \quad 4.4$ Western Superior craton

4.4.1 Crustal geology that requires plate tectonics?

The western part of the Superior craton is cited as a type location for accretion of ribbon continents above subduction zones (Figure 14) (Percival et al., 2006).

658 Amalgamation of the western Superior craton is inferred from the similarity of modern geochemical arc signatures to its Archean calc-alkaline volcanic and plutonic rocks

660 (Wyman and Kerrich, 2009). Geochemical signatures of many tonalite-trondhjemitegranodiorites indicate residual garnet and $\mathrm{Nb}$-Ta-compatible titanate phases, but associated Archean basalts display characteristics of crustal assimilation and fractionation hybrids between crustal melts and alkali basalts (Bédard et al., 2013;

664 Barnes and Van Kranendonk, 2014). The scale, volcanic facies, and geochemical systematics of Archean calc-alkaline suites also differ from those of modern arcs

666 (Hamilton, 1998; Bédard, 2006; Bédard et al., 2013). Instead of the melting of subducted Archean oceanic crust, thick basaltic crust subcreted beneath a drifting continent's

668 leading edge (Figure 3) could melt to create TTG-like melts geochemically similar to those formed during shallow subduction (Smithies et al., 2003). One difference is that a 670 subducting slab is heated from above by forced convection in the mantle wedge so that only young slow-moving slabs can melt (van Keken et al., 2002). However, the

672 predicted yield of TTG within such a model is inadequate to explain the observed volumes (Bédard, 2006). The alternative subcretion of a basaltic plateau-type crust

674 formed in a near-stagnant lid regime could produce the observed larger volumes of 
TTG as discrete events, assuming a combination of radioactive heating, thermal

676 conduction from hot upwelling mantle, and magmatic underplating (Smithies et al., 2003; Foley et al., 2003; Bédard et al., 2013).

Dipping seismic reflectors on Lithoprobe sections previously interpreted as fossil subduction zones (Figure 15) (Calvert et al., 1995; White et al., 2003) may instead mark 680 where crustal material was underthrust and subcreted, in a north to south sequence, to the leading edge of the drifting proto-craton (Bedard and Harris, 2014). This alternative

682 interpretation assumes that the Northern Superior cratonic block (Figure 14) began drifting south at $2.72 \mathrm{Ga}$ and that dipping crustal structures record tectonic imbrication

684 ahead and beneath the drifting continental block rather than serial subduction zones. Late Neoarchean metasedimentary belts (e.g., Quetico and English River belts) record 686 transient uplift and erosion during collision, followed by post-orogenic collapse (Calvert et al., 2004).

\subsubsection{Mantle geology}

The mantle xenolith record from the Superior craton is very sparse, especially 690 considering the large size of the craton. The only extensive studies performed so far are both on kimberlites from the Attawapiskat region (Scully et al., 2004; Smit et al.,

692 (2014a\&b). Peridotites erupted by the Victor and Delta kimberlites have high Mg\# (up to 93.1) indicating the presence of highly depleted dunite-harzburgite mantle stabilized 694 in the Eo-Mesoarchean (3.6 Ga: Smit et al., 2014a). This age is older than any crustal age in the North Caribou Superterrane but broadly coincident with crustal ages (3.8-3.5 Ga) 696 at Assean Lake in Manitoba and the Inukjuak domain in Quebec (Böhm et al., 2000; David et al., 2009). Neoarchean mantle depletion ages are recorded by other similarly 698 depleted peridotites, that may have formed synchronous with the crustal accretion and differentiation processes described above. Low-Mg eclogites at Victor have been shown 
700 to have oceanic crustal precursors that were subsequently emplaced into the mantle (Smit et al., 2014a), likely during $2.7 \mathrm{Ga}$ accretion of the western Superior craton. well to the North of the midcontinent rift, they record a prominent $1.1 \mathrm{Ga}$ event in their

704 Re-Os isotope systematics that indicates significant modification by that major Mesoproterozoic event (Smit et al., 2014a). In contrast, the geotherm defined by 706 peridotites and xenocrysts from these locations reveals a mantle that had thermally equilibrated to a typical mantle geotherm by the Jurassic, with a total lithospheric thickness of circa $200 \mathrm{~km}$. In contrast, mantle xenocrysts erupted by the $1.1 \mathrm{Ga}$ Kyle Lake kimberlite sample a much shallower lithosphere $(\sim 150 \mathrm{~km})$, probably as the result of thermal distrurbance by the Mid-continent rift (Smit et al., 2014b). The implied generation of new diamonds at mid-lithosphere levels after the thermal pulse associated

712 with the Midcontinent Rift had subsided is further substantiated by studies of diamonds by Smit et al. (2014b) who found much lower nitrogen aggregation states and

714 a distinct carbon isotopic signature for diamonds in Jurassic versus Mesoproterozoic Attawapiskat area kimberlites.

Lithoprobe seismic surveys were interpreted to show shallowly dipping thrustaccretion surfaces in the lower crust (Figure 15) (White et al., 2003) and more steeply

718 dipping features in the mantle to $250 \mathrm{~km}$ depths without clear lateral or structural continuity between the two (Percival et al., 2006). No seismic attributes resemble those 720 of modern subduction zones such as northern Cascadia (Nicholson et al., 2005).

\section{Constructing the Canadian Shield---Proterozoic plate tectonics}

After Archean lithosphere became stabilized it probably had a thermal boundary 724 layer greater than $120 \mathrm{~km}$ thick that was compositionally layered with depleted 
peridotite at the bottom grading upward into a pyroxenite-rich layer and plagioclase-

726 rich TTG layer. These buoyant, strong cratons circulated on the surface of the Earth and interacted with similar cratons and smaller, weaker continental blocks. Lateral motion was driven by continuing sites of down-welling that gradually evolved into what we today recognize as subduction zones when thinner, more rigid lithosphere formed in divergence zones or rifts and began to cool, densify and sink. Where this oceanic lithosphere subducted along the margins of an established craton, cratonic detritus and volatiles began to recycle into the interior and eventually re-incorporated into the bases of cratons that are now 180-250 km thick (Dhuime et al., 2012). The melts and volatiles

734 derived from the subduction zones locally metasomatized the lithosphere and generally enhanced its conductivity by introducing carbon-rich fluids that also enhanced the 736 probability of eclogitic diamond formation (Shirey et al., 2013).

The Slave craton was affected in this way. The 1.88-1.84 Wopmay orogen along 738 its western margin (Figure 4) includes a dipping reflective surface within the uppermost mantle observed by the Lithoprobe transect in the south (Cook et al., 1999) and by 740 teleseismic studies along its shared border with the Slave craton (Bostock, 1998; Snyder et al., 2014). The Great Bear arc associated with this orogeny is recognized as a volcanic 742 arc, but its implication for subduction polarity remains uncertain (Hoffman, 1980; Jackson et al., 2013; Ootes et al., 2015, 2016). Widespread metasomatism and 744 recrystallization of the mantle occurred at this time in the central and northern Slave (Heaman and Pearson, 2010; Aulbach et al., 2013), but less so in the south (Kopylova and Caro, 2004; Kopylova et al., 2016). The quality of peridotitic diamonds is observed to increase to the south, suggesting that Proterozic metasomatism may have reset rock 748 ages and also degraded ancient diamonds within the Slave craton whilst introducing newer eclogitic ones (Helmstaedt, 2009; Gurney et al., 2010). 
The mutual borderland of the Rae and Superior cratons is occupied by the 1.91.87 Ga Trans-Hudson orogen (Figures 1 and 8)(Corrigan et al., 2009). At mantle depths

752 of 100-200 km the cratons may interact (Snyder et al., 2012). At the surface a collage of terranes with evolving names (Hearne, northern Hearne, Sugluk, MetaIncognita), a 754 micro-craton (Sask), and two batholiths (Wathaman and Cumberland) separate these cratons by several hundred kilometers (Ross et al., 2000; Snyder et al., 2012; Pehrsson et al., 2013). Neither long, linear batholiths/plutons are observed, nor foreland basins (but see St-Onge et al., 2006 for discussion). Lithoprobe seismic reflection profiling did not reveal dipping reflectors or other uncontestable evidence of subducted oceanic plates along the Trans-Hudson orogeny (Lucas et al., 1994), leading instead to interpretation of 760 the Hearne terrane as a collisional plateau entrapped in a cratonic vise (Ross et al., 2000). Lower crustal and mantle ages throughout the Rae craton lithosphere reset at 1.9-

$7621.87 \mathrm{Ga}$ (Petts et al., 2014; Liu et al., 2015) attest to the widespread thermo-mechanical effect of this collisional orogeny. Enhanced conductivity at $100-120 \mathrm{~km}$ depths is also 764 attributed to metasomatism at this time (Snyder et al., 2015), metasomatism that is clearly recorded in mantle xenoliths (Liu et al., 2015).

Proterozoic-age deformation also affected much if not all of the Wyoming craton. The most thoroughly documented deformation is associated with the 1.78-1.62

768 Cheyenne Belt along its southern margin (Figure 11) (Karlstrom et al., 2005). Xenolith suites and seismic surveys indicate that both Archean and Proterozoic rock wedges occur beneath the surface trace of this belt, but considerable disagreement continues as to whether the structural boundary generally dips north or south and whether it 772 includes a coherent slab (Figure 12) (Eggler et al., 1988; Karlstrom et al., 2005; Schultze et al., 2008). Recent 3-D conductivity models suggest a near-vertical boundary (Figure 774 13D) (Megbel et al., 2014). The 1.81-1.71 Ga Great Falls tectonic zone separates the northern margin of the Wyoming craton from the Medicine Hat block of similar age, 
776 and is generally thought to dip northward (Condit et al., 2015; Megbel et al., 2014). The eastern margin of the Wyoming craton is less distinct, but the Black Hills (Figure 11)

778 have ages of 1.9-1.7 Ga (Chamberlain et al., 2003). The most significant metasomatic activity in the craton's early history, prior to Laramide disruption, is documented by well-defined 1.8-1.7 Ga U-Pb ages from monazites within highly metasomatised mantle assemblages (Carlson and Irving, 1994; Rudnick et al., 1999), which can be clearly linked to the above crustal events. The overall resistive mantle lithosphere of the Wyoming craton suggests that this metasomatism was localized and not widespread within the mantle (Figure 13D) (Meqbel et al., 2014).

\section{Destroying cratons: the Wyoming craton and the Farallon slab}

Seismic tomography models indicate mantle with abnormally fast seismic wave speeds beneath the Wyoming craton to depths of $300 \mathrm{~km}$ (Schmandt and Humphreys, 2010; Humphreys et al., 2015). In map view, the elongate shape to the anomalous velocities at depth does not match the outline of the Wyoming craton at the surface (Figure 11). The volume of relative fast seismic wave speeds, typical of cratons and shields, is most obvious on depth slices of shear wave models at 80-160-km (Figures 1 and 11). In surface wave models, it appears as a southwest-projecting 'peninsula' to the North American shield bounded to the northwest by prominent slow wave-speeds associated with the Snake River Plain (Shen et al., 2013). Body-wave tomography (Schmandt and Humphreys, 2010) shows a similar association of fast P-wave speeds, but with more detail and lateral variability. In all seismic models, the western part of the Wyoming craton, now occupied by the Basin and Range and Snake River Plain, is underlain by anomalously slow wave speeds compared to other cratons.

Xenoliths and isostatic arguments suggest that Wyoming craton mantle is depleted of basalt (Carlson and Irving, 1994; Carlson et al., 2004; Schultze et al., 2008), 
but that its deep part is not typical Archean craton. Xenolith suites suggest that the base 802 of the original Archean mantle was eroded from 180-200 up to 140-150 km depth at some time between the Devonian and Eocene (Humphreys et al., 2015), and that the 804 deeper lithospheric mantle today is younger than $200 \mathrm{Ma}$ (Figure 12) (Carlson et al., 1999, 2004). The same xenolith suites from the Wyoming craton region discussed previously help to understand its mantle replacement. The Kelsey Lake and Sloan xenoliths from the Cheyenne Belt (Figure 11) were erupted during the Devonian and show no indication of Phanerozoic ages (Schulze et al., 2008). Three xenoliths from the Williams kimberlite erupted from $\sim 150 \mathrm{~km}$ depth at $48 \mathrm{Ma}$, have Os model ages reset to 380-260 Ma, and a single pyroxenite has been dated at 67-57 Ma (Carlson and Irving, 1994). Peridotites from the nearby 54-50 Ma Bearpaw minettes retain some Proterozoic

812 signatures but were heavily metasomatized by water-rich fluids during the Cretaceous and Tertiary; their chemistry suggests that potassic parent magmas reacted with

814 phlogopite-rich veins (Downes et al., 2004). This metasomatism is assumed to have weakened the mantle peridotite and made it more susceptible to tectonic erosion from

816 below (as discussed by Li et al., 2008, in the context of the Colorado Plateau). The essential effect of metasomatic weakening on otherwise highly robust cratonic mantle was shown by recent geodynamical modeling (Wang et al., 2015). In contrast, modeled plume impact cannot erode strong anhydrous cratonic mantle without pre-cursor 820 hydrous metasomatism that weakens rocks of the stable root. Abundant evidence of hydrous metasomatism of the Wyoming craton root exists, as outlined above. by newly accreted Jurassic oceanic mantle about 75-65 Ma in a three-stage process associated with the Sevier-Laramide orogeny (Humphreys et al., 2015). Flat-slab subduction and its consequent release of fluid into the overlying mantle first eroded 40$82650 \mathrm{~km}$ from the base of the Archean Wyoming craton lithosphere. Basalt-depleted ocean 
plateau mantle lithosphere of the Shatsky Rise conjugate part of the Farallon slab was

828 then emplaced during the early Laramide orogeny. Stratigraphically recorded vertical movement in this region suggests that the plateau's dense oceanic crust diffused into

830 the underlying asthenosphere at 70-75 Ma. Initiation of Colorado Mineral Belt magmatism about this time may mark a slab rupture in the Farallon slab along the

832 margin of the Shatsky Rise conjugate through which the dense crust descended and buoyant mineralizing fluids rose (Chapin, 2012; Humphreys et al., 2015).

\section{7. North American Summary}

Construction histories of Archean cratons remain poorly understood; their

836 destruction is even less clear because of, by definition, its rarity, but metasomatic weakening is an essential precursor (Foley, 2008; Wang et al., 2015). By assembling

838 geophysical and geochemical data in 3-D lithospheric models, a clearer understanding of the geometry of major structures within the Rae, Slave, Wyoming and western

840 Superior cratons of central North America is now possible. Little evidence exists of subducted slab-like geometries similar to modern oceanic lithosphere in these

842 construction histories. Underthrusting and wedging of proto-continental lithosphere is inferred from multiple dipping discontinuities, emphasizing the role of lateral accretion.

844 Archean continental building blocks may resemble the modern lithosphere of the Ontong-Java-Hikurangi oceanic plateau in geometry, size and shape. Compositionally,

846 such blocks best match either the highly depleted peridotites found in Phanerozoic arcmantle settings (Canil, 2004; Pearson and Wittig, 2008) or the sort of refractory

848 peridotite that would be predicted to form at Archean ocean spreading centres with hot mantle potential temperatures that initiate melting deeper and create thicker oceanic

850 lithosphere (Herzberg and Rudnick, 2012; Pearson and Wittig, 2014). Whatever the mode of formation, refractory mantle formed the proto-cores of cratons that thickened

852 by lateral accretion. Radiometric dating of mantle xenoliths provides estimates of rock 
types and ages at depth beneath sparse kimberlite occurrences, and these ages can be

854 correlated to surface rocks. The 3.6-2.6 Ga Rae, Slave and Wyoming cratons comprise smaller continental terranes that stabilized during a granitic bloom at 2.61-2.55 Ga. This

856 stabilization probably represents the final differentiation of early crust into a relatively homogeneous, uniformly thin (35-42 km), tonalite-trondhjemite-granodiorite crust with 858 pyroxenite layers near the Moho atop depleted lithospheric mantle 100 to $200 \mathrm{~km}$ thick. A long period of passive tectonics, diabase dyke intrusion and failed rifting followed.

860 Peak thermo-tectonic events at 1.86-1.7 Ga broadly metasomatized, mineralized and recrystallized mantle and lower crustal rocks, apparently making mantle peridotite

862 more 'fertile' in the lower sections of the cratonic roots and enhancing conductivity by introducing or concentrating sulfides or graphite throughout the lithosphere at 80-120

$864 \mathrm{~km}$ depths. This metasomatism also weakened the lithosphere or made it more susceptible to tectonic or chemical erosion. The arrival of the subducted Shatsky Rise conjugate part of the Farallon plate at the Wyoming craton at 65-75 Ma appears to have completely eroded and displaced the thus weakened base of the craton below 140-160 $\mathrm{km}$. This process replaced the old re-fertilized continental mantle with relatively young depleted oceanic mantle.

\section{A global perspective}

Lithospheric structure discussed here for the four North American cratons

872 provides interesting contrasts among each other, but also with structure observed elsewhere in the world (Table 1). A few will be briefly highlighted here.

The Yilgarn craton of western Australia is recognized to be constructed by amalgamation of at least two superterranes that can be defined by their distinct $\varepsilon \mathrm{Nd}$

876 signatures (Blewett et al., 2010 and references therein). The individual histories of the component terranes have similar relative timing intervals to those of North American 878 cratons already discussed, but also indicate two distinct construction phases (Table 1). 
This may be due either to their membership in a different supercontinent grouping of

880

882

884

886

888

890

892

894

896

898

900

902

904

cratons or else to an earlier phase of continent formation at 2.9 Ga (van Kranendonk et al., 2013).

The Slave and Rae cratons appear to have undergone widespread Proterozoic metasomatism whereas the central Wyoming craton did not, based largely on its less extensive enhanced mantle conductivity. The heavily silicified and metasomatized mantle of the Kaapvaal craton and the largely pristine dunite/harzburgite of the North Atlantic (western and eastern Greenland) craton provide a similar contrast where they have been much more thoroughly studied as of extensive diamond exploration. Simon et al. (2007) describe the processes that led to the magmaphile element depletion of the Kaapvaal cratonic lithospheric mantle and its subsequent re-enrichment in Si and incompatible trace elements. Most samples are characterized by Archean Os model ages and a decoupling between $\mathrm{Nd}$ and $\mathrm{Hf}$ isotope ratios, features most consistent with initial melting at 3.2 Ga preceding metasomatism by hydrous fluids and further melting to produce a harzburgitic residue. Fractional melting models suggest either $30 \%$ melting in the spinel field or else $20 \%$ melting in the garnet field followed by $20 \%$ spinel-facies melting. Garnet Nd-Hf isotope characteristics similarly indicate metasomatic trace element enrichment during melting followed by metasomatism of the Kaapvaal upper mantle, probably during amalgamation of smaller pre-existing terranes in the Late Archaean $(2.9 \mathrm{Ga})$.

Thin lithosphere beneath the eastern North China Craton (NCC) is now widely recognized, similar to the Archean Wyoming craton, but the mechanism and timing of the thinning are more contentious (Menzies et al., 2007). Peridotitic xenoliths from the Cretaceous (100 Ma) Fuxin basalts at the northern edge of the craton (Zheng et al., 2007) can be subdivided into three types, representative of other xenolith suites across the craton. The dominant (Type 1) lherzolites with olivine Mg\# 90 represent fertile mantle (5-12\% partial-melt extraction) that makes up much of the Late Mesozoic-Cenozoic 
906 lithosphere beneath the craton. Type 2 consists of harzburgites (olivine $\mathrm{Mg} \#>92$ ) interpreted as shallow relics of the Archean cratonic mantle. Type 3, minor lherzolite

908 xenoliths with olivine Mg\# 86 reflect the interaction of the lithosphere with magmas. The regional synthesis suggests that Mesozoic-Cenozoic lithospheric thinning and mantle replacement was heterogeneously distributed across the North China Craton in space and time. Lateral spreading of the lithosphere, accompanied by asthenospheric

912 upwelling and melt-peridotite interaction, is the most probable mechanism for lithospheric thinning beneath the eastern part of the craton. Subsequent cooling of the upwelled asthenosphere caused some re-thickening of the lithosphere; this overall more fertile and hence denser lithosphere resulted in widespread basin formation.

Rayleigh wave tomography of the central and western NCC resulted in a S-wave velocity model that shows two major low-velocity zones (Jiang et al., 2013). These two

918 zones extend to depths greater than $200 \mathrm{~km}$ and coincide with sites of Cenozoic magmatism and the narrow trans-tensional zone of the Cenozoic Shanxi-Shaanxi Rift, respectively. The Ordos Block in the western NCC is associated with high-velocity anomalies, interpreted as intact cratonic mantle root, but with a discernible low-velocity

922 layer at depths of $100-150 \mathrm{~km}$ due to metasomatism. Most workers conclude that the current highly heterogeneous lithospheric structure results from multiphase reworking

924 of pre-existing mechanically weak zones since the amalgamation of the craton, but no lithosphere replacement via flat-slab subduction is hypothesized.

\section{Discussion}

What role do cratons play in subsequent plate tectonic geodynamics? It could be 928 argued that cratons are key to preserving entire continents because cratons and shields form a central part of every continent today and during past supercontinent assemblies (Pearson and Wittig, 2008; Griffin et al., 2009). The North American continent has a uniquely large shield because east of the Rockies the entire continent is underpinned by 
932 Archean-Proterozoic mantle keel. This large shield emphasizes the geodynamic roles cratons can play in perturbing net rotation or causing slab flattening via the craton's

934 effect on mantle convection (O’Driscoll et al., 2012).

Cratonic roots in North America and indeed worldwide appear to have

936

938

940

942

944

946

948

950

\section{Conclusions}

maximum depths between 200 and $250 \mathrm{~km}$, as indicated by both seismic and mantle geotherm constraints (Priestley and McKenzie, 2006; Jordan and Paulsen, 2013). The thermally and mechanically robust nature of cratonic mantle roots preserves the record of melting from an early and protracted part of Earth's history - the Archean. This reservoir, today comprising about $2 \%$ of the volume of the upper mantle (Pearson and Nowell, 2002), generally exhibits extreme depletion in incompatible components, including water. As such it played a small role in subsequent melt generation on Earth, other than to act as a "lid" that controlled the depth of melting. Only the most deepseated, volatile-rich, small-volume melts managed to pierce this canopy, bringing with them a unique archive of the root. While the prolonged isolation of cratonic mantle from the homogenizing effects of mantle convection led to them accumulating some of the most extreme isotopic signatures measured in Earth's reservoirs (e.g., Carlson and Irving, 1994; Pearson et al., 1995), the extremely low abundances of $\mathrm{Hf}, \mathrm{Nd}$ and $\mathrm{Sr}$ in the peridotites mean that they contribute little to the isotopic signatures in the rest of the mantle. Only where the lithosphere becomes metasomatised can it be classified as "reenriched" in terms of its magma-generation capacity. Such metasomatised lithosphere in turn becomes the most vulnerable to removal via thermo-mechanical erosion.

some degree. These include the building of basic continental cratonic blocks during the Archean, assembly of cratons into the North American shield during the Proterozoic, 
coeval or subsequent weakening by metasomatism, and partial erosion or delamination 958 of the lithospheric base.

Initial ancient (4.0-2.8 Ga) continental lithosphere blocks formed via fractional 960 differentiation of an early Earth semi-stagnant lid into plagioclase-, pyroxene- and olivine-rich layers. These continental nuclei, several hundred kilometers wide and 90-

962 120-km thick, grew by lateral tectonic accretion of similar, but more juvenile blocks. Seismic observations document wedge-shaped discontinuity surfaces that

964 accommodated horizontal shortening, but no clear seismic evidence currently exists of surviving pyroxene-rich drips or deeply subducted lithospheric slabs from this period.

966 Isotopic evidence does indicate coeval recycling of near-surface rocks into sublithospheric mantle, possibly via pyroxene-rich drips. These composite blocks cooled

968 sufficiently by about 2.6 Ga to possess the strength and buoyancy to survive subsequent collisions and become stabilized cratons.

Once subduction started about $2.8 \mathrm{Ga}$, Archean cratonic blocks eventually interacted and collided along mostly Proterozoic orogenic belts to form a North 972 American continental shield that has largely survived to the present. Today this shield has layered lithosphere that generally gets younger with depth and is $180-220 \mathrm{~km}$ thick.

974 Seismic discontinuities beneath many Proterozoic orogenic belts document subduction of intact (oceanic?) lithospheric slabs as is observed in modern subduction zones.

976 Sub-cratonic lithosphere is pervasively metasomatized and locally melted or recrystallized numerous times wherever it has been studied to date via xenoliths or as 978 inferred from enhanced conductivity. Upwardly migrating small percentage melt intrusions apparently introduce pyroxene-garnet (eclogite) assemblages, often with associated diamonds. Metasomatic fluids are often reducing and significantly weaken the lithosphere. These fluids are apparently rich in carbonates, silica or brine and 982 therefore widely enhance conductivity as shallow as $90-120 \mathrm{~km}$ depths. 
Old, stacked, weakened sub-cratonic lithosphere is variably eroded or

984 underplated by asthenospheric convection. Sparse indicators of lithosphere thickness during the Phanerozoic suggest thicknesses of 150-220 km. Subsidence or uplift

986 indicated by surface basins is modest, only a few kilometers. One prominent exception is the Wyoming craton beneath which the Farallon flat slab was subducted. This process removed the Archean lithospheric base below about $140 \mathrm{~km}$ and replaced it with Mesozoic oceanic lithosphere.

\section{Acknowledgments}

992 B. Kjarsgaard and J. Bedard provided comments on an early draft. This collaboration grew out of a Meierjurgen Fellowship awarded to DBS at the University of Oregon. GH 994 acknowledges support from the CIDER program (EAR-1135452) and from National Science Foundation grant EAR-0952194. DGP acknowledges funding from the Canada

996 Excellence Research Chairs Program. This is contribution \#20150111 to Natural Resource Canada's Open Geoscience Program.

998 References

Aulbach, S., 2012. Craton nucleation and formation of thick lithospheric roots. Lithos 149, 16100030.

Aulbach, S., Griffin, W.L., Pearson, N J. , O'Reilly, S.Y., 2013. Nature and timing of 1002 metasomatism in the stratified mantle lithosphere beneath the central Slave craton (Canada), Chem. Geol. 352, 153-169.

1004 Bao, X., Eaton, D.W., Guest, B., 2014. Plateau uplift in western Canada caused by lithospheric delamination along a craton edge. Nature Geosci. 7, 830-833.

1006 Bao, X., Eaton, D.W., 2015. Large variations in lithospheric thickness of western Laurentia: Tectonic inheritance or collisional reworking? Precambrian Res., 266, 579-586. 
1008 Barker, F., Arth, J.G., Millard, H.T., 1979. Archean trondhjemites of the southwestern Big Horn Mountains, Wyoming: a preliminary report. Trondhjemites, dacites, and related

1010

1012

1014

1016

1018

1020

1022

1024

1026

1028

1030

1032

1034

1036

1038

1040 rocks. Edited by F. Barker. Elsevier, Amsterdam, The Netherlands, 401-414.

Barnes, S.J., Van Kranendonk, M.J., 2014. Archean andesites in the east Yilgarn craton, Australia: Products of plume-crust interaction? Lithosphere 6, 80-92.

Bédard, J.H., 2006. A catalytic delamination-driven model for coupled genesis of Archaean crust and sub-continental lithospheric mantle. Geochim. Cosmochim. Acta, 70, 1188-1214.

Bédard, J.H., Harris, L.B., Thurston, P.C., 2013. The hunting of the snArc. Precambrian Res. 229, 20-48.

Bédard, J.H., Harris, L.B., 2014. Neoarchean disaggregation and reassembly of the Superior Craton. Geology 42, 951-954.

Berman, R.G., Davis, W.J. Pehrsson, S., 2007. The collisional Snowbird tectonic zone resurrected: growth of Laurentia during the 1.9 Ga accretionary phase of the TransHudson orogeny. Geology 35, 911-914.

Berman, R.G., Pehrsson, S.L., Davis, W.L., Ryan, W.L., Qui, H., Ashton, K., 2013. The Arrowsmith orogeny: geochronological and thermobarometric constraints on its extent and tectonic setting in the Rae craton, with implications for pre-Nuna supercontinent reconstruction. Precambrian Res. 232, 44-69.

Bleeker, W., 2002. Archean tectonics: a review, with illustrations from the Slave craton, in The Early Earth: Physical, Chemical and Biological Development, edited by C. M. R. Fowler, C. J. Ebinger, and C. J. Hawkesworth, Geol. Soc. London Spec. Pub. 199, 151-181.

Bleeker, W., 2003, Archean tectonics: a review, with illustrations from the Slave craton, in The Early Earth: Physical, Chemical and Biological Development, edited by C. M. R. Fowler, C. J. Ebinger, and C. J. Hawkesworth, Geol. Soc. London Spec. Pub. 199, 151-181.

Bleeker, W.J., Ketchum, W.F., Jackson, V.A., Villeneuve, M., 1999. The Central Slave Basement Complex, Part I: its structural topology and authochthonous cover. Can. J. Earth Sci. 36, 1083-1109.

Blewett, R.S., Czarnota, K., Henson, P.A., 2010. Structural-event framework for the eastern Yilgarn Craton, Western Australia, and its implications for orogenic gold. Precambrian Res. 183, 203-229.

Böhm, C.O., Heaman, L.M., Creaser, R.A. and Corkery, M.T., 2000. Discovery of pre-3.5 Ga exotic crust at the northwestern Superior Province margin, Manitoba. Geology, 28, 75-78. Bostock, M.G., 1998. Seismic stratigraphy and evolution of the Slave province. J. Geophys. Res. 103, 21183-21200. 
1042 Boyd, F.R., 1989. Compositional distinction between oceanic and cratonic lithosphere. Earth Planet. Sci. Lett. 96, 15-26.

1044 Burdick, L.J., Langston, C.A., 1977. Modeling crustal structure through the use of converted phases in teleseismic body-wave forms. Bull. Seis. Soc. America 67, 677-691.

1046 Calvert, A.J., Sawyer, E.W., Davis, W.J., Ludden, J.N., 1995. Archean subduction inferred from seismic images of a mantle suture in the Superior Province. Nature 375, 670-674.

1048 Calvert, A.J., Cruden, A.R., Hynes, A., 2004. Seismic evidence for preservation of the Archean Uchi granite-greenstone belt by crustal-scale extension. Tectonophysics 388, 135-143.

1050 Canil, D., 2004. Mildly incompatible elements in peridotites and the origins of mantle lithosphere. Lithos 77, 375-393.

1052 Carlson, R.W. Irving, A.J., 1994. Depletion and enrichment history of subcontinental lithospheric mantle: an $\mathrm{Os}, \mathrm{Sr}, \mathrm{Nd}$ and $\mathrm{Pb}$ isotopic study of ultramafic xenoliths from the northwestern Wyoming Craton. Earth Planet. Sci. Lett 126, 457-472.

Carlson, R.W., Irving, A.J., Hearn Jr., B.C., 1999. Chemical and isotopic systematics of

1056 peridotite xenoliths from the Williams kimberlite, Montana: clues to processes of lithosphere formation, modification and destruction. In Proc.VIIth International

1058 Kimberlite Conference 1, 90-98.

Carlson, R.W., Irving, A.J., Schulze, D.J., Hearn, B.C., 2004. Timing of Precambrian melt

1060 depletion and Phanerozoic refertilization events in the lithospheric mantle of the Wyoming Craton and adjacent Central Plains Orogen. Litho, 77, 453-472.

1062 Chamberlain K.R., Fros,t C.D., Frost, B.R., 2003. Early Archean to Mesoproterozoic evolution of the Wyoming Province: Archean origins to modern lithospheric architecture. Can. J.

1064 Earth Sci. 40, 1357-1374.

Chapin, C.E., 2012. Origin of the Colorado Mineral Belt, Geosphere 8, 28-43; doi:

1066 10.1130/GES00694.1.

Chave, A.D., Jones, A.G., 2012. The magnetotelluric method: Theory and practice. Cambridge $1068 \quad$ University Press.

Clifford T.N., 1966. Tectono-metallogenic units and metallogenic provinces of Africa. Earth 1070 Planet. Sci. Lett. 1, 421-434.

Cook, F.A., Erdmer, P., 2005. An 1800 An 1800 km cross section of the lithosphere through 1072 the northwestern North American plate: lessons from 4.0 billion years of Earth's history. Can. J. Earth Sci. 36, 1295-1311. 
1074 Cook, F.A., van der Velden, A., Hall, K.W., Roberts, B.J., 1999. Frozen subduction in Canada's Northwest Territories: LITHOPROBE deep lithospheric reflection profiling of the western

1076 Canadian Shield. Tectonics 18, 1-24.

Cooper, C.M., Lenardic, A., Moresi, L., 2004. The thermal structure of stable continental 1078 lithosphere within a dynamic mantle. Earth Planet. Sci. Lett. 222, 807-817.

Cooper, C.M., Conrad, C.P., 2009. Does the mantle control the maximum thickness of 1080 cratons? Lithosphere, 1, 67-72.

Condit, C.B., Mahan, K.H., Ault, A.K., Flowers, R.M., 2015. Foreland-directed propagation of 1082 high-grade tectonism in the deep roots of a Paleoproterozoic collisional orogen, SW Montana, USA. Lithosphere 7, 625-645.

1084

Corrigan, D., Pehrsson, S., Wodicka, N., De Kemp, E., 2009. The Palaeoproterozoic TransHudson Orogen: a prototype of modern accretionary process. In: Murphy, J.B., Keppie, J.D., Hynes, A.J. (Eds.), Ancient Orogens and Modern Analogues. Geol. Soc. London, Spec. Pub. 327, 457-479.

1088

Crosswhite, J., Humphreys, E., 2003. Imaging the Mountainless Root of the 1.8 Ga Cheyenne Suture and Clues to its Tectonic Stability, Geology 31, 669-672.

Crowley, J.W., R. O'Connell, in press, An analytic parameterized thermal convection model with finite-strength plates and depth-dependent rheology. J. Geophys. Res.

Currie, C.A. and van Wijk, J., 2016. How craton margins are preserved: Insights from geodynamic models. J. Geodynamics 100, 144-158.

David, J., Godin, L., Stevenson, R., O'Neil, J. and Francis, D., 2009. U-Pb ages (3.8-2.7 Ga) and $\mathrm{Nd}$ isotope data from the newly identified Eoarchean Nuvvuagittuq supracrustal belt, Superior Craton, Canada. Geol. Soc. America Bull. 121, 150-163.

Davis, W.J., Bleeker, W., 1999. Timing of plutonism, deformation, and metamorphism in the Yellowknife Domain, Slave Province, Canada. Can. J. Earth Sci. 36, 1169-1187.

Davis, W.J., Canil, D., MacKenzie, J.M., Carbno, G.B,. 2003. Petrology and U-Pb geochronology of lower crustal xenoliths and the development of a craton, Slave Province, Canada. Lithos 71, 541-573.

Davis, W.J., Hanmer, S., Tella, S., Sandeman, H.A., Ryan, J.J., 2006. U/Pb geochronology of the MacQuoid supracrustal belt and Cross Bay plutonic complex; key components of the northwestern Hearne Subdomain, western Churchill Province, Nunavut, Canada. Precamb. Res. 145, 53-80.

1106 Davis, W.J., Berman, R., Kjarsgaard, B., 1995. U-Pb geochronology and isotopic studies of crustal xenoliths from the Archean Medicine Hat block, northern Montana and southern 
1108 Alberta: Paleoproterozoic reworking of Archean crust. Alberta basement transects. Lithoprobe report 47, 329-334.

1110 Dhuime, B., Hawkesworth, C.J., Cawood, P.A., Storey, C.D., 2012. A change in the geodynamics of continental growth 3 billion years ago. Science 335, 1334-1336.

1112 Doin, M.P., Fleitout, L. Christensen, U., 1997. Mantle convection and stability of depleted and undepleted continental lithosphere. J. Geophys. Res. 102(B2), 2771-2787.

1114 Downes, H., Macdonald, R.A.Y., Upton, B.G., Cox, K.G., Bodinier, J.L., Mason, P.R., ... Hearn, B.C., 2004. Ultramafic xenoliths from the Bearpaw Mountains, Montana, USA: Evidence for multiple metasomatic events in the lithospheric mantle beneath the Wyoming craton. J. Petrol. 45, 1631-1662.

Eaton, D.W., Perry, H.C., 2013. Ephemeral isopycnicity of cratonic mantle keels. Nature Geoscience 6, 967-970.

Eggler, D.H., Meen, J.K., Welt, F., Dudas, F.O., Furlong, K.P., McCallum, M.E., Carlson, R.W., 1988. Tectonomagmatism of the Wyoming province. Colorado School Mines Quarterly 83, 25-40.

Eglington, B.M., S. Pehrsson, S., Ansdell, K.M., Lescuyer, J-M., Quirt, D., Milesi, J.-P., Brown, P., 2013. A domain-based digital summary of the evolution of the Palaeoproterozoic of North America and Greenland and associated unconformity-related uranium mineralization. Precambrian Res. 232, 4-26.

Elkins-Tanton, L.T., 2012. Magma oceans in the inner solar system. Ann. Rev. Earth . Planet. Sci. 40, 113-139.

Flowers, R.M., Royden, L.J., Bowring, S.A., 2004. Isostatic constraints on the assembly, stabilization, and preservation of cratonic lithosphere. Geology 32, 321-324.

Foley, S.F. 2008. Rejuvenation and erosion of the cratonic lithosphere. Nature Geoscience 1, 503-510.

Foley, S.F., Buhre, S., Jacob, D.E., 2003. Evolution of the Archaean crust by delamination and shallow subduction. Nature 421, 249.

Frost, C.D., Frost, B.R., Chamberlain, K.R., Hulsebosch, T.P., 1998. The Late Archean history of the Wyoming province as recorded by granitic magmatism in the Wind River Range, Wyoming. Precambrian Res. 89, 145-173. granodiorite (TTG) to granodiorite-granite (GG) transition in the late Archean plutonic rocks of the central Wyoming Province. Can. J. Earth Sci. 43, 1419-1444. 
Gorman, A.R., Clowes, R.M., Ellis, R.M., Henstock, T.J., Spence, G.D., Keller, G.R., ... Asudeh, I., 2002. Deep Probe: imaging the roots of western North America. Can. J. Earth Sci. 39, 375-398.

1144 Grace, R.L., Chamberlain, K.R., Frost, B.R., Frost, C.D., 2006. Tectonic histories of the Paleo-to Mesoarchean Sacawee block and Neoarchean Oregon Trail structural belt of the southcentral Wyoming Province. Can. J. Earth Sci. 43, 1445-1466.

Griffin, W.L., Doyle, B.J., Ryan, C.G., Pearson, N.J., O’Reilly, S.Y., Davies, R.M., Kivi, K., van Achterbergh, E., Natapov, L.M., 1999. Layered mantle lithosphere in the Lac de Gras area, Slave Craton: composition, structure, and origin, J. Petrology 40, 705-727.

Griffin, W.L., O'Reilly, S.Y., Afonso, J.C,. Begg, G.C., 2009. The composition and evolution of lithospheric mantle: A re-evaluation and its tectonic implications. J. Petrol. 50, 1185-1204.

Grütter, H.S., Apter, D.B, Kong, J., 1999. Crust-mantle coupling: evidence from mantlederived xenocrystic garnets. In: Gurney, J. J., Richardson, S. R. (Eds.), Proc. 7th kimberlite conference, Red Roof Designs, Cape Town, 307-312.

Gurney, J.J., Helmstaedt, H.H., Richardson, S.H., Shirey, S.B., 2010. Diamonds through time. Econ. Geol. Bull. Soc. Economic Geologists 105, 689-712, http://dx.doi.org/10.1093/petrology/egi029.

Hamilton, W.B., 1998. Archean magmatism and deformation were not products of plate tectonics. Precambrian Res. 91, 143-179.

Hamilton, W.B., 2015. Terrestrial planets fractionated synchronously with accretion, but Earth progressed through subsequent internally dynamic stages whereas Venus and Mars have been inert for more than 4 billion years. Geol. Soc. America Spec. Papers 514, SPE51409.

Hanmer, S., Bowring, S., van Breemen, O., Parrish, R., 1992. Great Slave Lake shear zone, NW Canada: mylonitic record of Early Proterozoic continental convergence, collision and indentation. J.Structural Geol. 14, 757-773.

Hanmer, S,. Tella, S., Ryan, J.J., Sandeman, , H.A., Berman, R.G., 2006. Neoarchean thick skinned thrusting and Paleoproterozoic reworking in the MacQuoid supracrustal belt and Cross Bay plutonic complex, western Churchill Province, Nunavut, Canada. Precambrian Res. 144, 126-139.

Harte, B., Harris, J.W., Hutchison, M.T., Watt, G.R., Wilding, M.C., 1999. Mantle petrology: field observations and high pressure experimentation: a tribute to Francis R.(Joe) Boyd. Geochem. Society Spec. Publ. 6, 125-153. 
1174 Heaman, L.M., Creaser, R.A., Cookenboo, H.O., Chacko, T., 2006. Multi-stage modification of the Northern Slave mantle lithosphere: evidence from zircon-and diamond-bearing

1176

1178 eclogite xenoliths entrained in Jericho kimberlite, Canada. J. Petrology, 47, 821-858.

Heaman, L.M., Pearson, D.G., 2010. Nature and evolution of the Slave Province

subcontinental lithospheric mantle. Can. J. Earth Sci. 47, 369-388.

Helmstaedt, H., 2009. Crust-mantle coupling revisited: the Archean Slave craton, NWT,

Helmstaedt, H.H., Pehrsson, S.J., 2012. Geology and Tectonic Evolution of the Slave Province-

A Post-Lithoprobe Perspective In: Percival J.A., Cook F.A., Clowes R.M. (eds.) Tectonic Styles in Canada: The Lithoprobe Perspective. Geological Association of Canada 379-466.

Henstock, T.J., Levander, A., Snelson, C.M., Keller, G.R., Miller, K.C., Harder, S.H., Gorman, A.R., Clowes, R.M., Burianyk, M.J.A., Humphreys, E.D., 1998. Probing the Archean and Proterozoic lithosphere of western North America. GSA Today, 8, 1-5.

Herzberg, C., Rudnick, R. 2012. Formation of cratonic lithosphere: An integrated thermal and petrological model. Lithos 149, 4-15.

Herzberg C., Condie K., Korenaga J. 2010. Thermal history of the Earth and its petrological expression. Earth Planet. Sci. Lett. 292, 79-88.

Hinchey, A.M., W. J. Davis, J. J. Ryan, L. Nadeau, 2011. Neoarchean high-potassium granites of the Boothia mainland area, Rae domain, Churchill Province: $\mathrm{U}-\mathrm{Pb}$ zircon and $\mathrm{Sm}-\mathrm{Nd}$ whole rock isotopic constraints. Can. J. Earth Sci. 48, 247-279.

Hoffman, P.F., 1980. Wopmay orogen: a Wilson cycle of early Proterozoic age in the northwest of the Canadian Shield. In: Strangway, D.W. (ed.) The continental crust and its mineral deposits. Geol. Assoc.Canada Special Paper 20, 523-549.

Hoffman, P.F., 1988. United Plates of America, the birth of a craton-Early Proterozoic assembly and growth of Laurentia. Ann. Rev. Earth Planet. Sci. 16, 543-603.

Hoffman, P.F., 2014. The origin of Laurentia: Rae craton as the backstop for Proto-Laurentian Amalgamation by slab suction. Geoscience Canada 41, 313-320.

Hopper, E., Ford, H.A., Fischer, K.M., Lekic, V. and Fouch, M.J., 2014. The lithosphereasthenosphere boundary and the tectonic and magmatic history of the northwestern United States. Earth Planet. Sci. Lett. 402, 69-81.

Houston, R.S., Erslev, E.A., Frost, C.D., Karlstrom, K.E., Page, N.J., Zientek, M.L., ... Reynolds, M.W., 1993. The Wyoming Province. Precambrian: Conterminous US. Boulder, Colorado, Geol. Soc. America, Geology of North America, 2, 121-170. 
Humphreys, E.D., Schmandt, B., Bezada, M.J., Perry-Houts, J., 2015. Recent craton growth by slab stacking beneath Wyoming. Earth Planet. Sci. Lett. 429, 170-180.

Irvine, G.J., Pearson, D.G., Kjarsgaard, B.A., Carlson, R.W., Kopylova, M.G., Dreibus, G., 2003. A Re-Os isotope and PGE study of kimberlite-derived peridotite xenoliths from Somerset Island and a comparison to the Slave and Kaapvaal cratons. Lithos 71, 461-488. Ishikawa, A., Pearson, D.G., Dale, C.W., 2011. Ancient Os isotope signatures from the Ontong Java Plateau lithosphere: Tracing lithospheric accretion history. Earth Planet. Sci. Lett. 301, 159-170.

Jackson, V.A., van Breemen, O., Ootes, L., Bleeker, W., Bennett, V., Davis, W.J., ... Smar, L., 2013. U-Pb zircon ages and field relationships of Archean basement and Proterozoic intrusions, south-central Wopmay Orogen, NWT: implications for tectonic assignments. Can. J. Earth Sci. 50, 979-1006.

Jaupart, C., Molnar, P., Cottrell, E., 2007. Instability of a chemically dense layer heated from below and overlain by a deep less viscous fluid. J. Fluid Mechanics 572, 433-469.

Jaupart, C., Mareschal, J.C., Bouquerel, H., Phaneuf, C., 2014. The building and stabilization of an Archean Craton in the Superior Province, Canada, from a heat flow perspective. J. Geophys. Res. Solid Earth 119, 9130-9155.

Jiang, M., Ai, Y., Chen, L., Yang, Y., 2013. Local modification of the lithosphere beneath the central and western North China Craton: 3-D constraints from Rayleigh wave tomography. Gondwana Res. 24, 849-864.

Jones, A.G., Lezaeta, P., Ferguson, I.J., Chave, A.D., Evans, R.L., Garcia, X., Spratt, J., 2003. The electrical structure of the Slave craton. Lithos 71, 505-527.

Jones, A.G., Ledo, J., Ferguson, I.J., Craven, J.A., Unsworth, M.J., Chouteau, M., Spratt, J.E., 2014. The electrical resistivity of Canada's lithosphere and correlation with other parameters: contributions from Lithoprobe and other programmes. Can. J. Earth Sci. 51, 573-617.

Jordan, T.H., 1978. Composition and development of the continental tectosphere. Nature 274, 544-548.

Jordan, T.H., Paulson, E.M., 2013. Convergence depths of tectonic regions from an ensemble of global tomographic models. J. Geophys.1 Res. 118(8), 4196-4225.

Kamber, B.S., 2015. The evolving nature of terrestrial crust from the Hadean, through the Archaean, into the Proterozoic. Precambrian Res. 258, 48-82.

Karlstrom, K.E., Whitmeyer, S.J., Dueker, K., Williams, M.L., Bowring, S.A., Levander, A.R., Humphreys, E.D., Keller, G.R., CD-ROM Working Group, 2005. Synthesis of Results from 
the Cd-Rom Experiment: 4-D Image of the Lithosphere Beneath the Rocky Mountains and Implications for Understanding the Evolution of Continental Lithosphere. In: Kalstrom, K.E., Keller, G.R. (eds), The Rocky Mountain Region: An Evolving Lithosphere Tectonics, Geochemistry, and Geophysics. Am. Geophys. Union, Washington, D. C. doi: 10.1029/154GM31.

Kennedy, L.A., Russell, J.K., Kopylova, M.G., 2002. Mantle shear zones revisited: The connection between the cratons and mantle dynamics. Geology 30, 419-422.

Kilian, T.M., Chamberlain, K.R., Evans, D.A., Bleeker, W., Cousens, B.L., 2016. Wyoming on the run-Toward final Paleoproterozoic assembly of Laurentia. Geology 44, 863-866.

Kopylova, M.G., Caro, G., 2004. Mantle xenoliths from the southeastern Slave craton: evidence for chemical zonation in a thick, cold lithosphere. J. Petrol. 45, 1045-1067.

Kopylova, M.G., Russell, J.K., Cookenboo, H., 1999. Petrology of peridotite and pyroxenite xenoliths from the Jericho kimberlite: implications for the thermal state of the mantle beneath the Slave craton, northern Canada. J. Petrology 40, 79-104.

Kopylova, M.G., Beausoleil, Y., Goncharov, A., Burgess, J., Strand, P., 2016. Spatial distribution of eclogite in the Slave cratonic mantle: The role of subduction. Tectonophysics 672, 87-103.

Krogh, T.E., Kamo, S.L., Hanley, T.B., Hess, D.F., Dahl, P.S., Johnson, R.E., 2011.

Geochronology and geochemistry of Precambrian gneisses, metabasites, and pegmatite from the Tobacco Root Mountains, northwestern Wyoming craton, Montana. Can. J. Earth Sci. 48, 161-185.

LaFlamme, C., McFarlane, C.R.M., Corrigan, D., N. Wodicka, 2014. Origin and tectonometamorphic history of the Repulse Bay Block, Melville Peninsula, Nunavut; exotic terrane or deeper level of the Rae Craton? Can. J. Earth Sci. 51, 1097-1122.

Lee, C-T.A., Chin, E.J., 2014. Calculating melting temperatures and pressures of peridotite protoliths: Implications for the origin of cratonic mantle. Earth Planet. Sci. Lett. 403, 273286.

Lee, C-T.A., Luffi, P., Chin, E. J., 2011. Building and destroying continental mantle. Ann. Rev. Earth Planet. Sci. 39, 59-90.

Lenardic, A., Moresi, L.N., Mühlhaus, H., 2003. Longevity and stability of cratonic lithosphere: insights from numerical simulations of coupled mantle convection and continental tectonics. J. Geophys. Res. Solid Earth, 108, 1-15.

Levander, A., Miller, M.S., 2012. Evolutionary aspects of lithosphere discontinuity structure in the western US. Geochem. Geophys. Geosys. 13(7). 
Li, Z.X.A., Lee, C.T.A., Peslier, A.H., Lenardic, A., Mackwell, S.J., 2008. Water contents in

1276

1278

1280

1282

1284

1286

1288

1290

1292

1294

1296

1298

1300

1302

1304

1306

1308 mantle xenoliths from the Colorado Plateau and vicinity: Implications for the mantle rheology and hydration- induced thinning of continental lithosphere. J. Geophys. Res.: Solid Earth 113, B09210.

Liu, J., Riches, A.J., Pearson, D.G., Luo, Y., Kienlen, B., Kjarsgaard, B.A., ... Armstrong, J.P., 2015. Age and evolution of the deep continental root beneath the central Rae craton, northern Canada. Precambrian Res. 272, 168-184.

Lockhart, G., Grütter, H., Carlson, J., 2004. Temporal, geomagnetic and related attributes of kimberlite magmatism at Ekati, Northwest Territories, Canada. Lithos 77, 665-682.

Lucas, S.B., White, D., Hajnal, Z., Lewry, J., Green, A., Clowes, R., Zwanzig, H., Ashton, K., Schledewitz, D., Stauffer, M., Norman, A., 1994. Three-dimensional collisional structure of the Trans-Hudson Orogen, Canada. Tectonophysics 232, 161-178.

Mather, K.A., 2013. A xenolith-based transect of the Slave craton, NWT, Canada Doctoral dissertation, Durham University, UK.

Mather, K.A., Pearson, D.G., McKenzie, D., Kjarsgaard, B.A., Priestley, K. , 2011. Constraints on the depth and thermal history of cratonic lithosphere from peridotite xenoliths, xenocrysts and seismology. Lithos 125, 729-742.

Menzies, M., Xu, Y., Zhang, H., Fan, W., 2007. Integration of geology, geophysics and geochemistry: a key to understanding the North China Craton. Lithos 96, 1-21.

Meqbel, N.M., Egbert, G.D., Wannamaker, P.E., Kelbert, A., Schultz, A., 2014. Deep electrical resistivity structure of the northwestern US derived from 3-D inversion of USArray magnetotelluric data. Earth Planet. Sci. Lett. 402, 290-304.

Michaut, C., Jaupart, C., Mareschal, J.C., 2009. Thermal evolution of cratonic roots. Lithos 109, 47-60.

Miller, M.S., Eaton, D.W., 2010. Formation of cratonic mantle keels by arc accretion: Evidence from S receiver functions. Geophys. Res. Lett. 37, L18305, doi:10.1029/2010GL044366.

Mirnejad, H., Bell, K., 2006. Origin and source evolution of the Leucite Hills lamproites: evidence from $\mathrm{Sr}-\mathrm{Nd}-\mathrm{Pb}-\mathrm{O}$ isotopic compositions. J. Petrology 47, 2463-2489.

Mitchell, R.H., 2008. Petrology of hypabyssal kimberlites: relevance to primary magma compositions. J.Volc. Geothermal Res. 174, 1-8.

Mogk, D.W., Mueller, P.A., Wooden, J.L., 1992. The nature of Archean terrane boundaries: an example from the northern Wyoming Province. Precambrian Res. 55, 155-168.

Mueller, P.A., Frost, C.D., 2006. The Wyoming Province: a distinctive Archean craton in Laurentian North America. Can. J. Earth Sci. 43, 1391-1397. 
Nicholson, T., Bostock, M., Cassidy, J.F., 2005. New constraints on subduction zone structure in northern Cascadia. Geophys. J. Intern. 161, 849-859.

Nixon, P.H., 1987. Mantle xenoliths.

1312 O'Driscoll, L.J., Richards, M.A., Humphreys, E.D., 2012. Nazca-South America interactions and the late Eocene-late Oligocene flat- slab episode in the central Andes. Tectonics, 31, 2, doi:10.1029/2011TC003036.

Ootes, L., Davis, W.J., Jackson, V.A., van Breemen, O., 2015. Chronostratigraphy of the Hottah terrane and Great Bear magmatic zone of Wopmay Orogen, Canada, and exploration of a terrane translation model. Can. J. Earth Sci. 52, 1062-1092.

Ootes, L., Snyder, D., Davis, W.J., Acosta-Gongora, P., Corriveau, L., Mumin, A.H., Gleeson, S.A., Samson, I.M., Montreuil, J-F., Potter, E., Jackson, V.A., 2016. A Paleoproterozoic Andean-type iron oxide copper-gold environment, the Great Bear magmatic zone, Northwest Canada, Ore Geol. Rev. http://dx.doi.org/10.1016/j.oregeorev.2016.09.024

Pearson, D.G., Shirey, S.B., Carlson, R.W., Boyd, F.R., Pokhilenko, N.P., Shimizu, N., 1995. $\mathrm{Re}-\mathrm{Os}, \mathrm{Sm}-\mathrm{Nd}$ and $\mathrm{Rb}-\mathrm{Sr}$ isotope evidence for thick Archaean lithospheric mantle beneath the Siberian craton modified by multistage metasomatism. Geochim. Cosmochim. Acta 59, 959-977.

Pearson, D.G., Canil, D., Shirey, S.B., 2003. Mantle samples included in volcanic rocks: xenoliths and diamonds. Treatise Geochemistry 2, 171-275.

Pearson, D.G., Nowell, G.M., 2002. The continental lithospheric mantle: characteristics and significance as a mantle reservoir. Philos. Trans. Royal Soc. London A: Mathematical, Physical and Engineering Sciences 360.1800, 2383-2410.

Pearson, D.G., Wittig, N., 2008. Formation of Archean continental lithosphere and its diamonds: The root of the problem. J. Geol. Soc. London 165, 1-20.

Pearson, D.G., Wittig, N., 2014. 3.6-The Formation and Evolution of Cratonic Mantle Lithosphere-Evidence from Mantle Xenoliths. Treatise Geochemistry 2, 255-292, doi:10.1016/B978-0-08-095975-7.00205-9.

Pehrsson, S., Berman, R., Eglington, B., Rainbird, R., 2013. Two Neoarchean supercontinents revisted: The case for a Rae family of cratons. Precambrian Res., 232, 27-43. Tectonic evolution of the western Superior Province from NATMAP and Lithoprobe studies. Can. J. Earth Sci. 43, 1085-1117.

Percival, J.A., Skulski, T., Sanborn-Barrie, M., Stott, G.M., Leclair, A.D., Corkery, M.T., Boily, M., 2012. Geology and tectonic evolution of the Superior Province, Canada. Chapter 6 in 
Tectonic Styles in Canada: The LITHOPROBE Perspective. Percival, J.A., Cook, F.A.

1344

1346

1348

1350

1352

1354

1356

1358

1360

1362

1364

1366

1368

1370

1372

1374

Clowes, R.M. (eds.). Geol. Assoc. Canada, Special Paper 49, 321-378.

Peterson, T.D., Van Breemen, O., Sandeman, H., Cousens, B., 2002. Proterozoic (1.85-1.75 Ga)

igneous suites of the Western Churchill Province: Granitoid and ultrapotassic magmatism in a reworked Archean hinterland. Precambrian Res. 119, 73-100.

Peterson, T.D., Pehrsson, S., Skulski, T., Sandeman,H., 2010. Compilation of Sm-Nd Isotope Analyses of Igneous Suites, Western Churchill Province. Geol. Surv. Canada Open File 6439.

Petts, D.C., Davis, W.J., Moser, D.E., Longstaffe, F.J., 2014. Age and evolution of the lower crust beneath the western Churchill Province: $\mathrm{U}-\mathrm{Pb}$ zircon geochronology of kimberlitehosted granulite xenoliths, Nuavut, Canada. Precambrian Res. 241, 129-145.

Priestley, K., McKenzie, D., 2006, The thermal structure of the lithosphere from shear wave velocities, Earth Planet. Sci. Lett. 244, 285-301.

Rainbird, R. H., Davis, W.J., Pehrsson, S., Wodicka, N., Rayner, N., Skulski, T., 2010. Early

Paleoproterozoic supracrustal assemblages of the Rae domain, Nunavut, Canada:

intracratonic basin development during supercontinent break-up and assembly.

Precambrian Res. 181, 167-186.

Roberts, N.M., Spencer, C.J., 2015. The zircon archive of continent formation through time.

Geol. Soc.London Spec. Pub. 389, 197-225.

Rosen, O.M., Condie, K.C., Natapov, L.M., Nozhkin, A.D., 1994. Archean and Early

Proterozoic evolution of the Siberian craton: a preliminary assessment. Archean Crustal Evolution 11, 411-459.

Ross G.M., Eaton D.W., Boerner D.E., Miles W. 2000. Tectonic entrapment and its role in the evolution of the continental lithosphere: An example from the Precambrian of western Canada. Tectonics 19, 116-134.

Rudnick, R.L., McDonough, W.F., O'Connell, R.J., 1998. Thermal structure, thickness and composition of continental lithosphere. Chemical Geology 145, 395-411.

Rudnick, R.L., Ireland, T.R., Gehrels, G., Irving, A.J., Chesley, J.T., Hanchar, J.M., 1999.

Dating mantle metasomatism: $\mathrm{U}-\mathrm{Pb}$ geochronology of zircons in cratonic mantle xenoliths from Montana and Tanzania. Proc. 7th International Kimberlite Conf. 2, 728-735.

Sarkar, C., Heaman, L.M. and Pearson, D.G., 2015. Duration and periodicity of kimberlite volcanic activity in the Lac de Gras kimberlite field, Canada and some recommendations for kimberlite geochronology. Lithos 218, 155-166. 
1376

1378

1380

1382

1384

1386

1388

1390

1392

1394

1396

1398

1400

1402

1404

1406

1408

Sanborn-Barrie, M., Davis, W.J., Berman, R.G., Rayner, N., Skulski, T., and Sandeman, H., 2014. Neoarchean continental crust formation and Paleoproterozoic deforemation of the central Rae craton, Committee Bay belt, Nunavut. Can. J. Earth Sci. 51, 635-667.

Schaeffer, A.J., Lebedev, S., 2014. Imaging the North American continent using waveform

$$
\text { inversion of global and USArray data. Earth Planet. Sci. Lett. 402, 26-41, }
$$
doi.org/10.1016/j.epsl.2014.05.014.

Schmandt, B., Humphreys, E., 2010. Complex subduction and small-scale convection revealed by body-wave tomography of the western United States upper mantle. Earth Planet. Sci. Lett. 297, 435-445.

Schmidberger, S.S., Simonetti, A., Heaman, L.M., Creaser, R.A., Whiteford, S., 2007. Lu-Hf, in-situ $\mathrm{Sr}$ and $\mathrm{Pb}$ isotope and trace element systematics for mantle eclogites from the Diavik diamond mine: Evidence for Paleoproterozoic subduction beneath the Slave craton, Canada. Earth Planet. Sci. Lett. 25, 55-68.

Schulze, D.J., Coopersmith, H.G., Harte, B., Pizzolato, L.A., 2008. Mineral inclusions in diamonds from the Kelsey Lake Mine, Colorado, USA: Depleted Archean mantle beneath the Proterozoic Yavapai province. Geochim. Cosmo. Acta 72, 1685-1695.

Scully, K.R., Canil, D., Schulze, D.J., 2004. The lithospheric mantle of the Archean Superior Province as imaged by garnet xenocryst geochemistry. Chemical Geology 207, 189-221. Shen, W., Ritzwoller, M.H., Schulte- Pelkum, V., 2013. A 3- D model of the crust and uppermost mantle beneath the Central and Western US by joint inversion of receiver functions and surface wave dispersion. J. Geophys. Res.: Solid Earth 118, 262-276.

Shirey, S.B., Richardson, S.H., 2011. Start of the Wilson cycle at 3 Ga shown by diamonds from subcontinental mantle. Science 333, 434-436.

Shirey, S.B., Shigley, J.E., 2013. Recent advances in understanding the geology of diamonds. Gems Gemology 49, 188-222..

Shirey, S.B., Cartigny, P., Frost, D.J., Keshav, S., Nestola, F., Nimis, P., Pearson, D.G., Sobolev, N.V., Walter, M.J., 2013. Diamonds and the geology of mantle carbon. Rev. Mineral Geochem. 75, 355-421.

Siddorn, J., Cruden, A., Hauser, R., Armstrong, J., Kirkham, G., 2006. The Giant-Con Gold Deposits: Preliminary Intergrated Structural and Mineralisation History. Geol. Assoc. Canada Spec. Pub. 3, 213-231.

Sigloch, K., 2011. Mantle provinces under North America from multifrequency P wave tomography. Geochem. Geophys. Geosys. 12(2). 
Simon, N.S., Carlson, R.W., Pearson, D.G., Davies, G.R., 2007. The origin and evolution of the Kaapvaal cratonic lithospheric mantle. J. Petrology, 48, 589-625.

Sizova, E., Gerya, T., Brown, M., Perchuk, L.L., 2010. Subduction styles in the Precambrian: insight from numerical experiments. Lithos 116, 209-229.

Skulski, T., Sandeman, H., Sanborn-Barrie, M., MacHattie, T., Young, M., Carson, C., Berman, R., Brown, R., Rayner, N., Panagapko, D., Byrne, D., Deyell, C., 2003. Bedrock geology of the Ellice Hills map area and new constraints on the regional geology of the Committee Bay area, Nunavut. Current Research Geological Survey of Canada paper C22, 1-11.

Sleep, N.H., 2003. Survival of Archean cratonal lithosphere. J. Geophys. Res. Solid Earth, 108, $1-29$.

Sleep, N.H. 2009. Stagnant lid convection and carbonate metasomatism of the deep continental lithosphere. Geochem. Geophys. Geosys. 10(11).

Smit, K., Pearson, D.G., Stachel, T., Seller, M., 2014a. Peridotites from Attawapiskat, Canada: Mesoproterozoic reworking of Palaeoarchaean lithospheric mantle beneath the Northern Superior superterrane. J. Petrology 55, 1829-1863.

Smit, K.V., Stachel, T., Creaser, R.A., Ickert, R.B., DuFrane, S.A., Stern, R.A., Seller, M., $2014 b$. Origin of eclogite and pyroxenite xenoliths from the Victor kimberlite, Canada, and implications for Superior craton formation. Geochim. Cosmo. Acta 125, 308-337.

Smithies, R.H., Champion, D.C., Cassidy, K.F., 2003. Formation of Earth's early Archaean continental crust. Precambrian Res. 127, 89-101.

Snyder, D.B., Grütter, H.S., 2010. Lithoprobe's impact on the Canadian diamond-exploration industry. Can. J. Earth Sci. 47, 783-800.

Snyder, D.B., Kjarsgaard, B.A., 2013. Mantle roots of major Precambrian shear zones inferred from structure of the Great Slave Lake shear zone, northwest Canada. Lithosphere 5, 539546.

Snyder, D.B., Berman, R.G., Kendall, J-M., Sanborn-Barrie, M., 2012. Seismic Anisotropy and Mantle structure of the Rae craton, central Canada, from joint interpretation of SKS splitting and receiver functions. Precambrian Res., 232, 189-208, doi: 10.1016/j.precamres.2012.03.003.

Snyder, D.B., Hillier, M.J., Kjarsgaard, B.A., de Kemp, E.A., Craven, J.A., 2014. Lithospheric architecture of the Slave craton, northwest Canada, as determined from an interdisciplinary 3-D model. Geochem. Geophys. Geosys. 15(5), 1895-1910.

Snyder, D.B., Craven, J.A., Pilkington, M., Hillier, M.J., 2015. The 3-dimensional construction of the Rae craton, central Canada. Geochem. Geophys. Geosys. 16(10), 3555-3574. 
Snyder, G.L., Hall, R.P., Hughes, D.J., Ludwig, K.R., 1990. Early Precambrian basic rocks of

1444

1446

1448

1450

1452

1454

1456

1458

1460

1462

1464

1466

1468

1470

1472

1474 the USA. In: Early Precambrian basic magmatism, 191-220. Springer Netherlands.

Solomatov, V.S., Stevenson, D.J., 1993. Nonfractional crystallization of a terrestrial magma ocean. J. Geophys. Res. 98, 5391-5406.

Spencer, C.J., Cawood, P.A., Hawkesworth, C.J., Raub, T.D., Prave, A.R., Roberts, N.M., 2014. Proterozoic onset of crustal reworking and collisional tectonics: Reappraisal of the zircon oxygen isotope record. Geology 42, 451-454.

Spratt, J.E., Skulski, T., Craven, , J.A., Jones, A.G., Snyder, D.B., Kiyan, D., 2014.

Magnetotelluric Investigations of the lithosphere beneath the central Rae craton, mainland Nunavut, Canada. J. Geophys. Res. Solid Earth, 119, 2415-2439.

Stachel, T., Brey, G.P. and Harris, J.W., 2005. Inclusions in sublithospheric diamonds: glimpses of deep Earth. Elements 1, 73-78.

St-Onge, M.R., Searle, M., Wodicka, N., 2006. Trans-Hudson Orogen of North America and Himalyan-Tibetan Orogen of Asia: Structural and thermal characteristics of the lower and upper plates. Tectonics 25, TC4006, doi:10.1029/2005TC001907.

Tainton, K.M., McKenzie, D.A.N., 1994. The generation of kimberlites, lamproites, and their source rocks. J. Petrology, 35, 787-817.

Tappe, S., Pearson, D.G., Kjarsgaard, B.A., Nowell, G., Dowall, D., 2013. Mantle transition zone input to kimberlite magmatism near a subduction zone: Origin of anomalous Nd-Hf isotope systematics at Lac de Gras, Canada. Earth Planet. Sci. Lett. 371, 235-251.

Tommasi, A., Ishikawa, A., 2014. Microstructures, composition, and seismic properties of the Ontong Java Plateau mantle root. Geochem. Geophys. Geosys. 15(11), 4547-4569.

van Keken, P.E., Hauri, E.H., Ballentine, C.J., 2002. Mantle mixing: the generation, preservation, and destruction of chemical heterogeneity. Ann. Rev. Earth Planet. Sci. 30, 493-525.

Van Kranendonk, M.J., 2010. Two types of Archean continental crust: Plume and plate tectonics on early Earth. Am. J. Sci. 310, 1187.

Van Kranendonk, M.J., Ivanic, T.J., Wingate, M.T., Kirkland, C.L., Wyche, S., 2013. Longlived, autochthonous development of the Archean Murchison Domain, and implications for Yilgarn Craton tectonics. Precambrian Res. 229, 49-92.

Wang, H., van Hunen, J., Pearson, D.G., Allen, M.B., 2014. Craton stability and longevity: The roles of composition-dependent rheology and buoyancy. Earth Planet. Sci. Lett. 391, 224233. 
1476 Wang, H., van Hunen, J., Pearson, D.G., 2015. The thinning of subcontinental lithosphere: the roles of plume impact and metasomatic weakening. Geochem. Geophys. Geosys. 28,

1478 doi:10.1002/2015GC005784.

Weiss, Y., McNeill, J., Pearson, D.G. , Nowell, G.M., Ottley, C.J., 2015. Highly saline fluids

1480 from a subducting slab as the source for fluid-rich diamonds. Nature, 524, 339-342.

White, D.J. , Musacchio, G., Helmstaedt, H.H., Harrap, R.M., Thurston P., van der Velden, A.,

1482 Hall, K., 2003. Images of a lower-crustal oceanic slab; direct evidence for tectonic accretion in the Archean western Superior Province. Geology 31, 997-1000.

1484 Wirth, E.A., Long, M.D., 2014. A contrast in anisotropy across mid-lithospheric discontinuities beneath the central United States-A relic of craton formation. Geology 42, 1486 851-854.

Wyman, D., Kerrich, R., 2009. Plume and arc magmatism in the Abitibi subprovince:

1488 implications for the origin of Archean continental lithospheric mantle. Precambrian Res.168, 4-22.

1490 Yuan, H., Romanowicz, B., Fischer, K. M., Abt, D., 2011. 3-D shear wave radially and azimuthally anisotropic velocity model of the North American upper mantle. Geophys. J.

1492 Int. 184, 1237-1260.

Zheng, J.P., Griffin, W.L., O’Reilly, S.Y., Yu, C.M., Zhang, H.F., Pearson, N., Zhang, M., 2007. 1494 Mechanism and timing of lithospheric modification and replacement beneath the eastern North China Craton: peridotitic xenoliths from the $100 \mathrm{Ma}$ Fuxin basalts and a regional 1496 synthesis. Geochim. Cosmo. Acta 71, 5203-5225. 
Figure captions

1500 Figure 1. Map of the North America shield as outlined at $90-\mathrm{km}$ depth by positive relative S-wave speed (\% of average model) tomography (modified from Schaeffer and 1502 Lebedev, 2014). The four principal Archean cratons of North America are outlined at 90 km depth by dashed white lines. THO is the Trans Hudson Orogen; MISH is the Meta1504 Incognito-Sugluk-Hearne micro continent (Snyder et al., 2012).

Figure 2. Schematic cross sections showing development of early Earth lithosphere 1506 tectonics (modified from Lee and Chin, 2014). Specific rock ages (Ga) indicated are taken from the Slave craton, but appear generally representative of the time frame 1508 observed on numerous cratons worldwide (Table 1). Black lines are form lines of observed structures; diamonds indicate diamond source regions. Mantle lithosphere 1510 structures from this time are not observed and presumed destroyed by later tectonics and convection.

1512 Figure 3. Schematic cross section (a) showing amalgamation of Archean cratons into Proterozoic shields. Fundamental building blocks (yellow) are typically 100-120 km 1514 thick, and similar in composition to oceanic plateaus (b) today (modified from Tommasi and Ishikawa, 2014). These blocks were thrust over or under neighboring lithosphere on 1516 low-angle shear zones (MLD). Note presumed absence of thin oceanic lithosphere.

Figure 4. Simplified basement geology map of the Slave craton. Dashed lines labelled 1518 CSBC outline the most ancient block, the Central Slave Basement Complex (Bleeker et al., 1999). Squares labelled A, J, E, D, GQ, S, DB locate mantle xenolith suites source 1520 locations at the Anuri (prospect), Jericho, Ekati, Diavik, Gahcho Kue, Snap Lake, and Dry Bones (prospect) diamond mines, respectively. Dash-dot-dot lines locate cross 1522 sections of Figure 6. 
Figure 5. Two north-looking perspectives of a lithospheric-scale 3-D model of Slave

1524 craton structures inferred from seismic discontinuities and xenolith studies (modified from Snyder et al., 2014). Five structural surfaces are observed: a horizontal Moho

1526 (green), an undulating (LGD) surface at about 100-km depth (royal blue), a northeastdipping surface associated with the Hottah terrane (red), an east-dipping surface

1528 associated with the Ft. Simpson slab (blue), and a horizontal mid-lithospheric discontinuity (MLD) at 140-150 km depth (gold). The latter is mapped primarily by its seismic anisotropy, but also coincides with a marked increase in surface wave velocity (Yuan et al., 2011). Picks for two other discontinuities are represented by yellow and blue dots for easier viewing; these wedge-shaped discontinuities partly delimit the central and east Slave blocks at depth. J, D, and GQ are as in previous figure. Cones 1534 show 3D Ps receiver functions displayed at three representative seismic stations.

Figure 6. Summary cross sections of the Slave craton. Both sections illustrate that a 1536 Central Slave nucleus grew tectonically outward by wedging apart first the accreting East Slave block at 2.6 Ga, the Rae craton at 2.0-1.9 Ga, and then the Hottah terrane at 1.85 Ga. WF and MDF are the Wopmay and MacDonald strike-slip faults. Numbers are rock ages in Ga (Heaman and Pearson, 2010). The vertical columns labelled J, D, and 1540 QG are xenolith suite rock types from Jericho, Diavik/Ekati, and Gahcho Que, respectively (Kopylova and Caro, 2004; Snyder and Karsgaard, 2014). K is the coastal 1542 town of Kugaruk. Dashed lines mark seismic discontinuities. LAB is the lithosphereasthenosphere boundary inferred from geotherms (Mather et al., 2011). H, X, and L are 1544 discontinuities as interpreted by Bostock (1998) and discussed in the text.

Figure 7. Lithospheric-scale 3-D conductivity model of Slave craton (modified from 1546 Snyder et al., 2014). View is from the south. Parts of the Hottah and LDG surfaces are visible at about 100-km depth (see Figure 5). Conductivity appears to be everywhere 1548 enhanced by the extensive reducing metasomatism that affected the lithosphere at 
depths greater than about 100-km. In a few locations (e.g., D) equally conductive 1550 regions continue upward into the crust, mostly near known kimberlite fields or mineralized zones. Yellow dots, J, D, and GQ are as in Figure 5. Tiny red dots are other 1552 discontinuity picks.

Figure 8. Simplified basement geology map of the Rae craton (modified from Berman et 1554 al., 2013). Dashed lines locate sections of Figures 6 and 10. C is the Committee Bay block, QM the Queen block, CB the Cumberland batholith, $\mathrm{Cb}$ the Chesterfield block, $\mathrm{M}$ 1556 the Melville Peninsula, MI the MetaIncognita terrane, Rb the Repulse Bay block, and WB the Wathaman batholith.

1558 Figure 9. Lithospheric-scale 3-D model of Rae craton structures, viewed from the northwest. Numerous surfaces are determined from seismic discontinuities in Ps 1560 receiver functions, most project upward toward major crustal structures such as the Central Structural Domain (CSD) or Chantrey fault (Ch) (Snyder et al., 2015). QM

1562 indicates a mantle surface that projects up to the Queen Maud block; Mel projects up to the central Melville Peninsula.

1564 Figure 10. Summary cross sections of the Rae craton. Dashed lines indicate seismic discontinuity surfaces here interpreted as thrust faults that thickened the Rae

1566 lithosphere. Solid black lines are faults interpreted from surface structures. Numbers are ages in $\mathrm{Ga}$; italics indicate tectonic events. Late metasomatism at depth is inferred 1568 from enhanced conductivity. Ch is the Chantrey fault, CSD is the Central Structural Domain, QM is the Queen Maud block, and CB is the Cumberland batholith. Q is the 1570 Qilaluquaq kimberlite with its xenolith suite rock and lithosphere base (LAB) paleodepths indicated below by rectangles (Liu et al., 2015).

1572 Figure 11. (a) Location map of the Wyoming craton with topography as background. Circles labeled BP, H, W, LH, K, S are xenolith suite locations Bearpaw, Homestead, 
1574 Williams, Leucite Hills, Kelsey Lake and Sloan, respectively. Heavy dashed lines mark major deformation zones. Lighter dashed line shows location of cross sections in Figure

1576 12. Dotted line marks a regional seismic traverse SAREX/Deep Probe (Gorman et al., 2002). Red line outlines interpreted limits of the Wyoming craton in the crust (Killian et

1578 al., 2016), green line outlines interpreted limits of the Shatsky conjugate part of the underthrust Farallon lithosphere as inferred from relatively greater wavespeeds of 1580 surface (b) and S-waves (c) (modified from Humphreys et al., 2015).

Figure 12. Summary cross sections of the Wyoming craton. Both sections illustrate that a 1582 Wyoming craton nucleus (Bighorn block) grew tectonically outward by wedging apart first the accreting Sierra Madre block at 2.62 Ga, and then the Green Mountain belt of 1584 the Yavapai terrane at 1.75 Ga. Numbers are rock ages in Ga (Chamberlain et al., 2003). The vertical columns labelled W\&H and KL\&S are xenolith suite rock types from 1586 Williams, Homestead, Kelsey Lake, and Sloan, respectively (Carlson et al., 2004; Schultze et al., 2008). CMB is the Colorado Mineral Belt; THO is the Trans-Hudson 1588 Orogen.

Figure 13. Lithsopheric-scale 3-D seismic tomography (A-C), conductivity (D), and Sp 1590 receiver function models of the Wyoming craton region (modified from Levander and Miller, 2012; Megbel et al., 2014; Humphreys et al., 2015), presented here as cross 1592 sections. Locations are shown on $160-\mathrm{km}$ depth slice of surface wave model. CB is Cheyenne belt, GFTZ is Great Falls tectonic zone, MHB is the Archean Medicine Hat 1594 block. Red triangle locates the Yellowstone caldera.

Figure 14. Simplified basement geology map of the western Superior craton (modified 1596 from Percival et al., 2006). Dashed lines locate sections of Figure 15.

Figure 15. (a) Crustal model of western Superior craton structures as defined by seismic 1598 reflections (modified from White et al., 2003). (b) Summary cross section of the western 
Superior craton. Ages are in Ga (modified from Percival et al., 2006). The most ancient

1600 block, the Northern Superior, grew southward by the wedging apart of and subsequent accretion of the North Caribou, Winnipeg River and Wabigoon terranes. ER and Q are 1602 the English River and Quentico metasedimentary belts. 
Table 1. Comparative radiometric ages of some cratons

\begin{tabular}{|c|c|c|c|c|c|c|}
\hline AGES (Ga) & $\begin{array}{l}\text { Slave } \\
\text { craton }^{1}\end{array}$ & Rae craton $^{2}$ & $\begin{array}{l}\text { Wyoming } \\
\text { craton }^{3}\end{array}$ & $\begin{array}{l}\text { Superior } \\
\text { craton }^{4}\end{array}$ & $\begin{array}{l}\text { Yilgarn } \\
\text { craton }^{5}\end{array}$ & $\begin{array}{l}\text { Kaapvaal } \\
\text { craton }^{6}\end{array}$ \\
\hline $\begin{array}{l}\text { Basement } \\
\text { gneiss }\end{array}$ & $\begin{array}{l}\text { 3.5-3.0 } \\
\text { (4.03 Acasta) } \\
\text { 3.4-2.7 ReOs }\end{array}$ & $\begin{array}{l}3.6-2.6 \\
\text { 3.0-2.5 ReOs }\end{array}$ & $\begin{array}{l}\text { 3.5-3.1 } \\
\text { Bighorn block } \\
\text { 3.3-3.1 TTGs }\end{array}$ & $\begin{array}{l}3.9-2.67 \\
\text { TTG }\end{array}$ & 3.3-2.67 TTG & 3.55-3.2 TTG \\
\hline Cover sequence & $\begin{array}{l}2.8 \text { C. Slave } \\
\text { C.S. }\end{array}$ & $\begin{array}{l}\text { 2.97 Prince } \\
\text { Albert Gp. }\end{array}$ & $\begin{array}{l}2.853 \text { Barlow } \\
\text { Gap }\end{array}$ & & & $\begin{array}{l}\text { 2.68-2.43 Black } \\
\text { Reef (Transvaal) }\end{array}$ \\
\hline $\begin{array}{l}\text { Juvenile } \\
\text { basement }\end{array}$ & $\begin{array}{l}2.75 \text { East } \\
\text { Slave }\end{array}$ & $\begin{array}{l}2.7-2.66 \\
\text { Hearne }\end{array}$ & $\begin{array}{l}2.65-2.60 \\
\text { Sierra Madre }\end{array}$ & & & \\
\hline Greenstones & $\begin{array}{l}2.73-2.58 \\
\text { Yellowknife } \\
\text { Gp. }\end{array}$ & $\begin{array}{l}\text { 2.74-2.69 } \\
\text { Committee } \\
\text { Bay }\end{array}$ & $\begin{array}{l}\text { (2.701 } \\
\text { Stillwater) } \\
2.55-2.45 \\
\text { mafic dykes }\end{array}$ & $2.75-2.695$ & $\begin{array}{l}2.96-2.93 \\
2.825-2.7 \\
\text { Murchison } \\
2.72-2.655 \\
\text { E Goldfields }\end{array}$ & $\begin{array}{l}2.710 \\
\text { Ventersdorp }\end{array}$ \\
\hline Turbidite basins & 2.66 Burwash & & $\begin{array}{l}2.73-2.67 \text { in } \\
\text { south }\end{array}$ & $\begin{array}{l}2.69-2.685 \\
\text { Porcupine }\end{array}$ & $\begin{array}{l}2.665-2.65 \\
\text { "late basins" }\end{array}$ & $\begin{array}{l}2.642-2.432 \\
\text { Prieska }\end{array}$ \\
\hline $\begin{array}{l}\text { Granites or } \\
\text { dykes }\end{array}$ & $\begin{array}{l}2.635-2.615 \\
\text { Defeat } \\
2.61-2.605 \\
\text { Concession } \\
2.59-2.58 \\
\text { Prosperous (2 } \\
\text { mica) } \\
\end{array}$ & $\begin{array}{l}2.72-2.68 \\
2.63-2.58 \\
\text { juvenile }\end{array}$ & $\begin{array}{l}2.72-2.67 \\
2.63-2.60 \\
2.55-2.50(2 \\
\text { mica) }\end{array}$ & $\begin{array}{l}2.719-2.67 \\
\text { TTG } \\
2.684- \\
2.677 \\
\text { "late" }\end{array}$ & $\begin{array}{l}2.67-2.55 \\
\text { High-Ca }\end{array}$ & \\
\hline $\begin{array}{l}\text { Peak } \\
\text { metamorphism }\end{array}$ & $2.60-2.59 \mathrm{Au}$ & $\begin{array}{l}2.5-2.3 \text { in } \\
\text { mantle }\end{array}$ & $2.55-2.45$ & $\begin{array}{l}2.673 \mathrm{Au} \\
2.645\end{array}$ & $2.65-2.63 \mathrm{Au}$ & 3.23 \\
\hline $\begin{array}{l}\text { Major } \\
\text { deformations }\end{array}$ & $\begin{array}{l}2.645-2.635 \\
\text { D2 } \\
1.88-1.84 \\
\text { Wopmay }\end{array}$ & $\begin{array}{l}2.56-2.5 \\
\text { MacQuoid } \\
2.1-1.9 \\
\text { Pilings Gp. } \\
1.9-1.87 \\
\text { Hudsonian } \\
\text { 1.87-1.77 } \\
\text { Nuelton } \\
\end{array}$ & $\begin{array}{l}2.65-2.60 \\
\text { Oregon Trail } \\
2.56 \\
1.78-1.62 \\
\text { Cheyenne } \\
\text { Belt }\end{array}$ & $<2.6$ & $\begin{array}{l}2.67 \\
\text { shortening } \\
2,72-2.66 \\
\text { doming }\end{array}$ & 2.47 Limpopo \\
\hline
\end{tabular}

\footnotetext{
${ }^{1}$ Bleeker, 2002; Helmstaedt and Pehrson, 2012

${ }^{2}$ Berman et al., 2013

${ }^{3}$ Chamberlain et al., 2003

${ }^{4}$ Percival et al., 2006; 2012

${ }^{5}$ Blewett et al. 2010; Van Kranendonk et al., 2013

${ }^{6}$ Shirey et al., 2013
} 


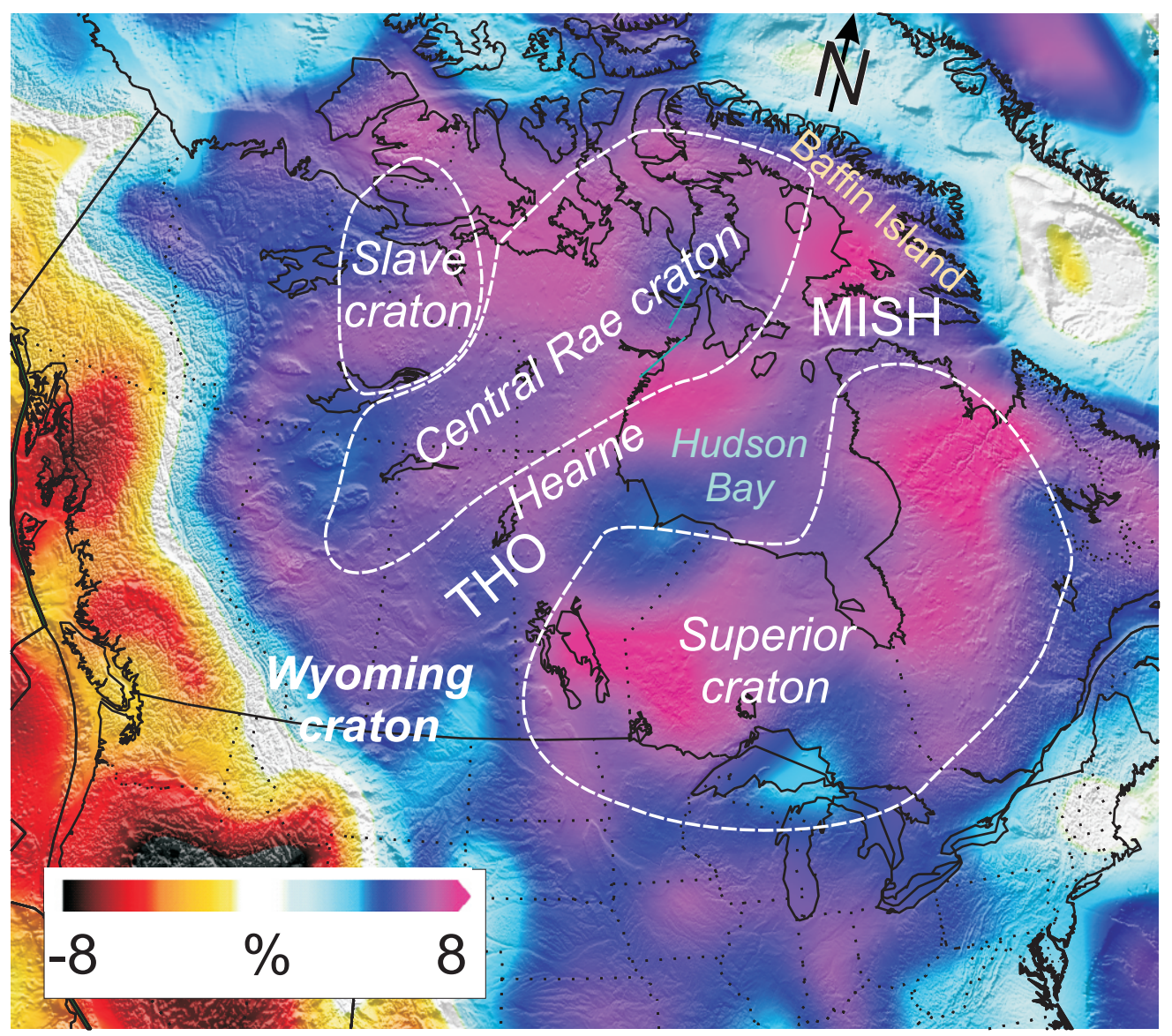

Figure 1. Map of the North America shield at $90-\mathrm{km}$ depth as outlined by positive relative S-wave speed (\% of average model) tomography (modified from Schaeffer \& Lebedev, 2014). The four principal Archean cratons of North America are outlined at $90 \mathrm{~km}$ depth by dashed white lines. 


$\diamond \quad$ Iherzolites $\quad \diamond \quad 3.4-2.7 \mathrm{Ga}$

sluggish lid, downwelling initiates

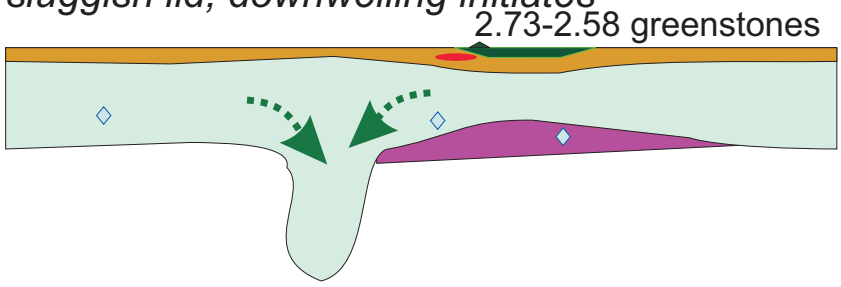

horizontal flow \& tectonics (D1)

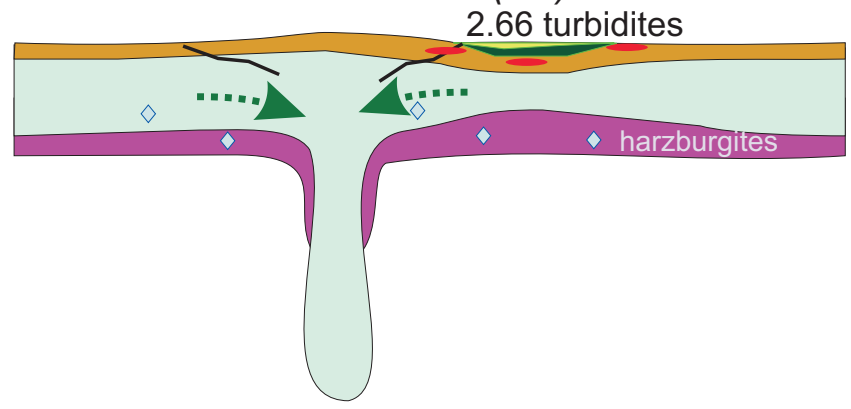

crust differentiates, peak metamorphism (D2), mineralization, cratonization

2.64-2.60 intermediate plutons; 2.58 2-mica granites

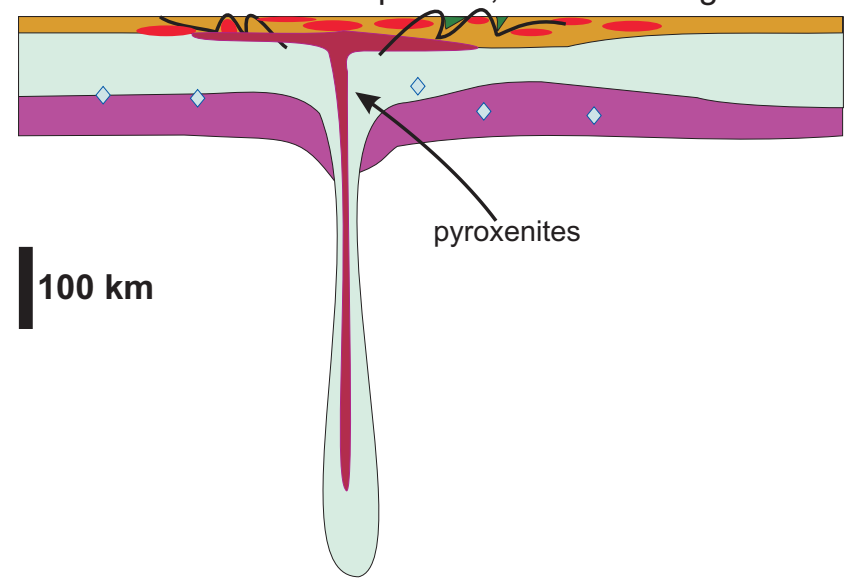

Figure 2. Schematic cross sections showing development of early Earth lithosphere tectonics (modified from Lee and Chin, 2015). Specific rock ages $(\mathrm{Ga})$ indicated are taken from the Slave craton, but appear generally representative of the time frame observed on numerous cratons worldwide (Table 1). Black lines are form lines of observed structures; diamonds indicate diamond source regions. 

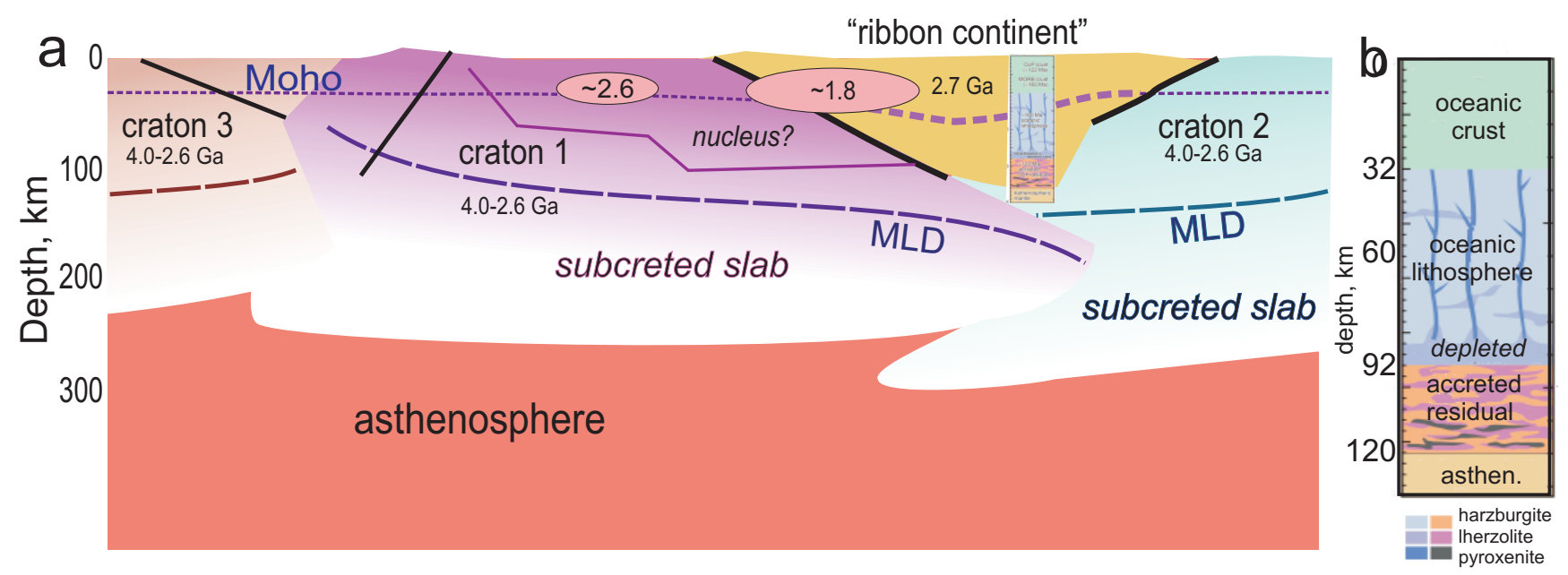

Figure 3. Schematic cross section (a) showing amalgamation of Archean cratons into Proterozoic shields. Fundamental building blocks (yellow) are typically 100-120 km thick, and similar in composition to oceanic plateaus (b) today (modified from Tommasi \& Ishikawa, 2014). These blocks were thrust over or under neighboring lithosphere on lowangle shear zones (MLD). Note presumed absence of thin oceanic lithosphere. 


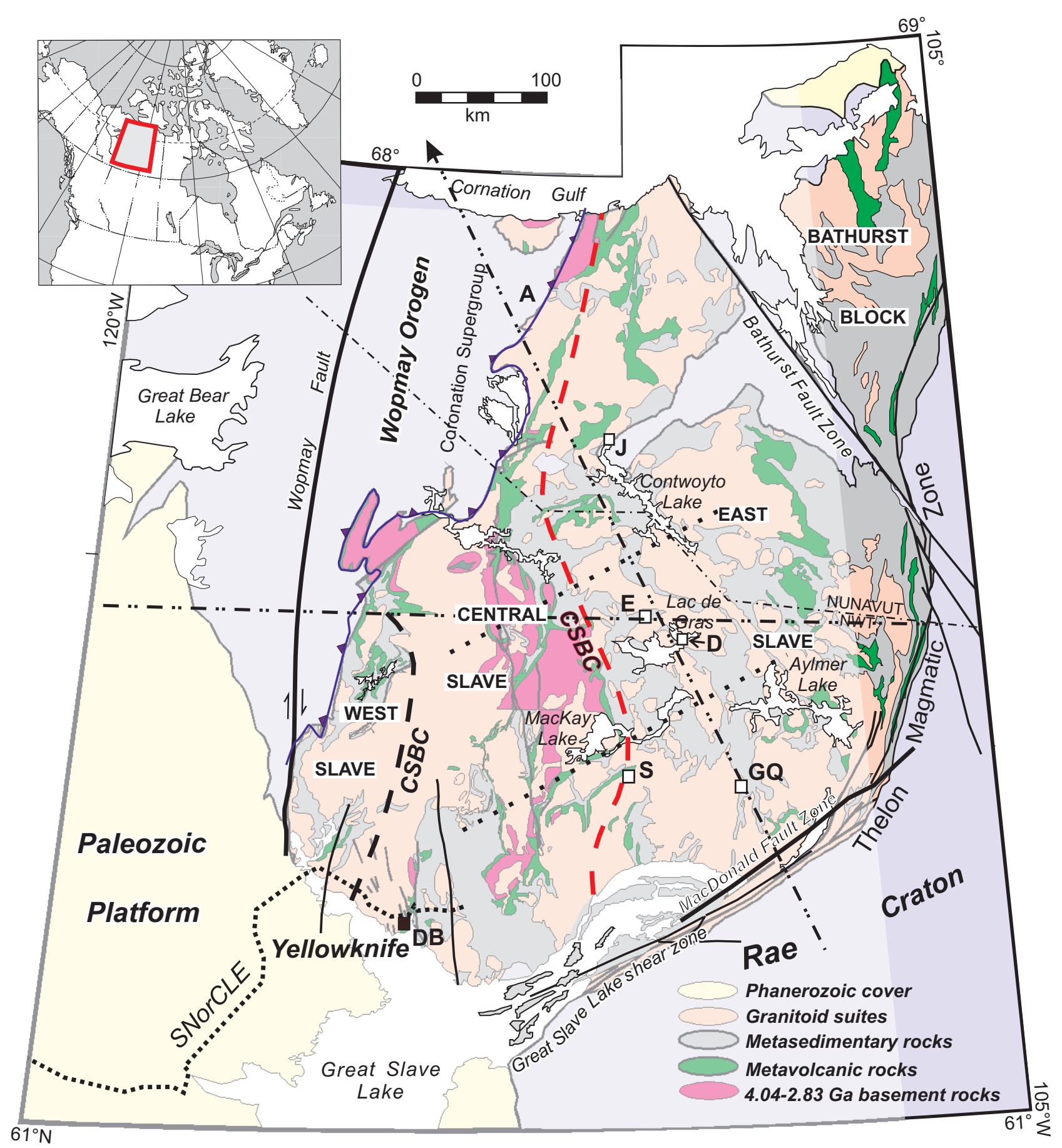

Figure 4. Simplified basement geology map of the Slave craton. Dashed lines labelled CSBC outline the most ancient block, the Central Slave Basement Complex (Bleeker et al., 1999). Squares labelled A, J, E, D, GQ, S , DB locate mantle xenolith suites source locations at the Anuri (prospect), Jericho, Ekati, Diavik, Gahcho Que, Snap Lake, and Dry Bones (prospect) diamond mines, respectively. Dash-dot-dot lines locate cross sections of Figure 6. 

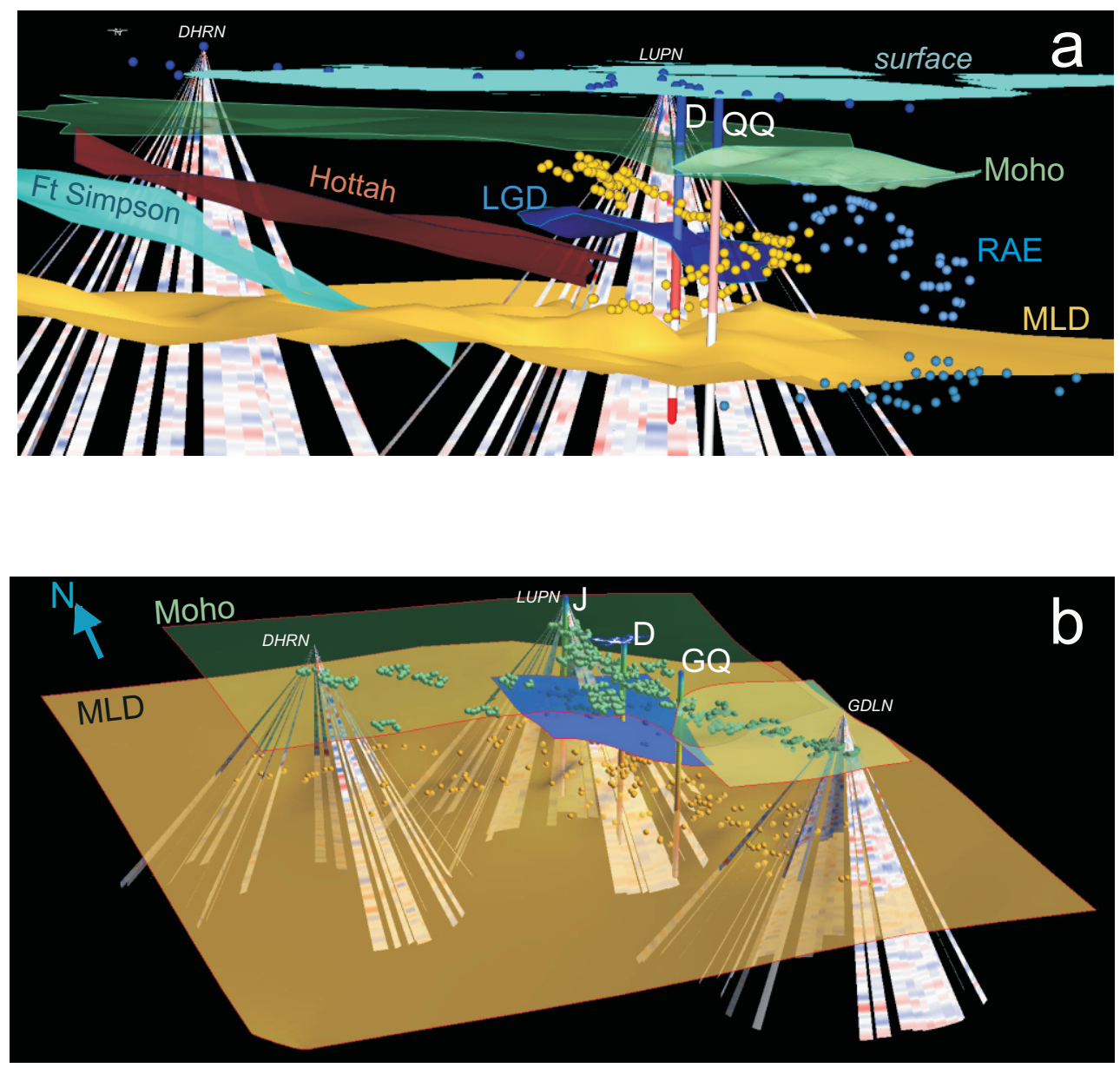

Figure 5. Two north-looking perspectives of a lithospheric-scale 3-D model of Slave craton structures inferred from seismic discontinuities and xenolith studies (modified from Snyder et al., 2014). Five structural surfaces are observed: a horizontal Moho (green), an undulating (LGD) surface at about 100-km depth (royal blue), a northeast-dipping surface associated with the Hottah terrane (red), an east-dipping surface associated with the Ft. Simpson slab (blue), and a horizontal mid-lithospheric discontinuity (MLD) at 140-150 $\mathrm{km}$ depth (gold). The latter is mapped primarily by its seismic anisotropy, but also coincides with a marked increase in surface wave velocity (Yuan et al., 2011). Picks for two other discontinuities are represented by yellow and blue dots for easier viewing; these wedge-shaped discontinuities partly delimit the central and east Slave blocks at depth. J, D, and GQ are as in previous figure. Cones show 3D Ps receiver functions displayed at three representative seismic stations. 


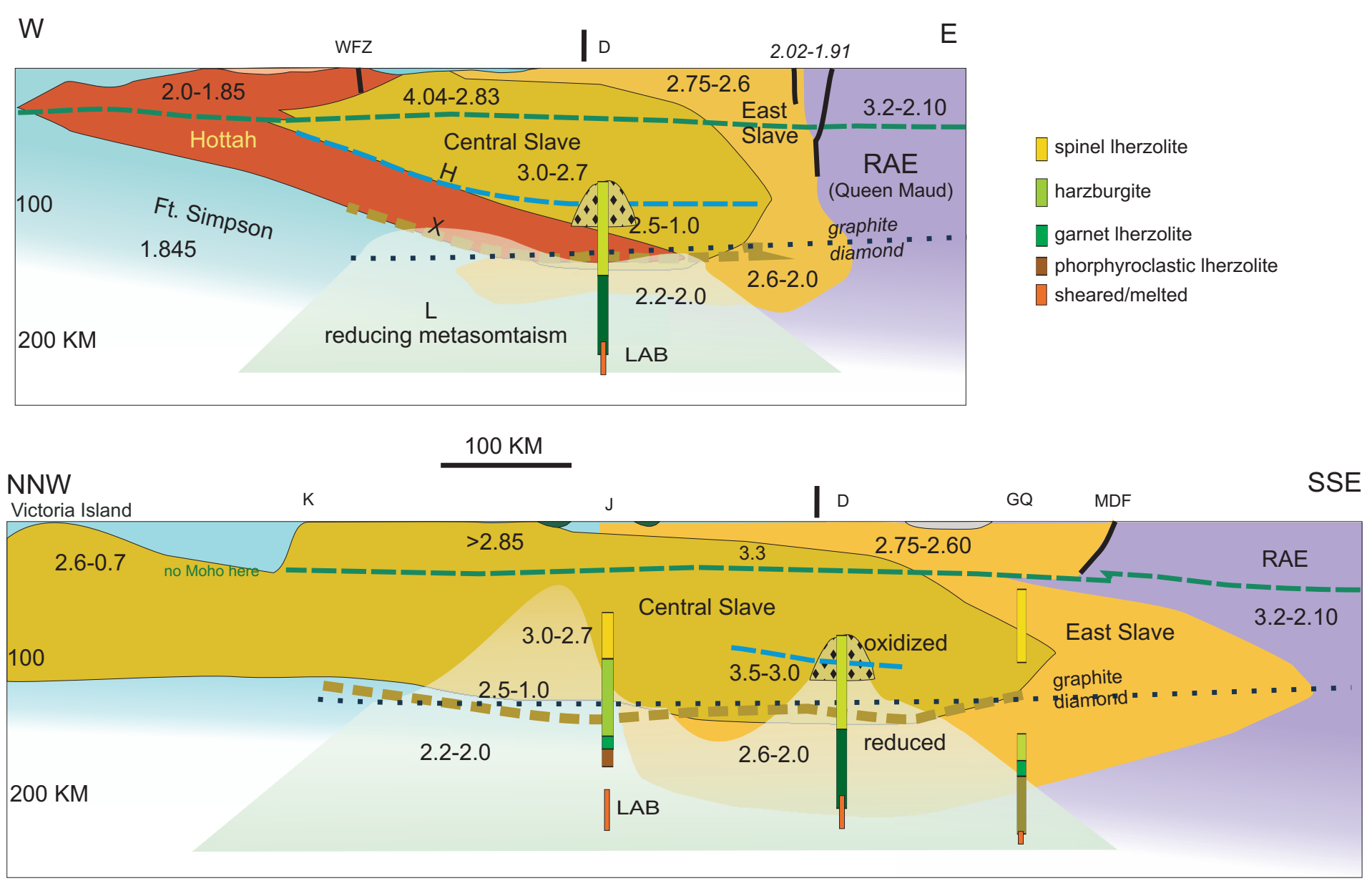

Figure 6. Summary cross sections of the Slave craton. Both sections illustrate that a Central Slave nucleus grew tectonically outward by wedging apart first the accreting East Slave block at $2.6 \mathrm{Ga}$, the Rae craton at 2.0-1.9 Ga, and then the Hottah terrane at 1.85 Ga. WF and MDF are the Wopmay and MacDonald strike-slip faults. Numbers are rock ages in Ga (Heaman and Pearson, 2010). The vertical columns labelled J, D, and QG are xenolith suite rock types from Jericho, Diavik/Ekati, and Gahcho Que, respectively (Kopylova \& Caro, 2004; Snyder \& Karsgaard, 2014). K is the coastal town of Kugaruk. Dashed lines mark seismic discontinuities. LAB is the lithosphere-asthenosphere boundary inferred from geotherms (Mather et al., 2011). 


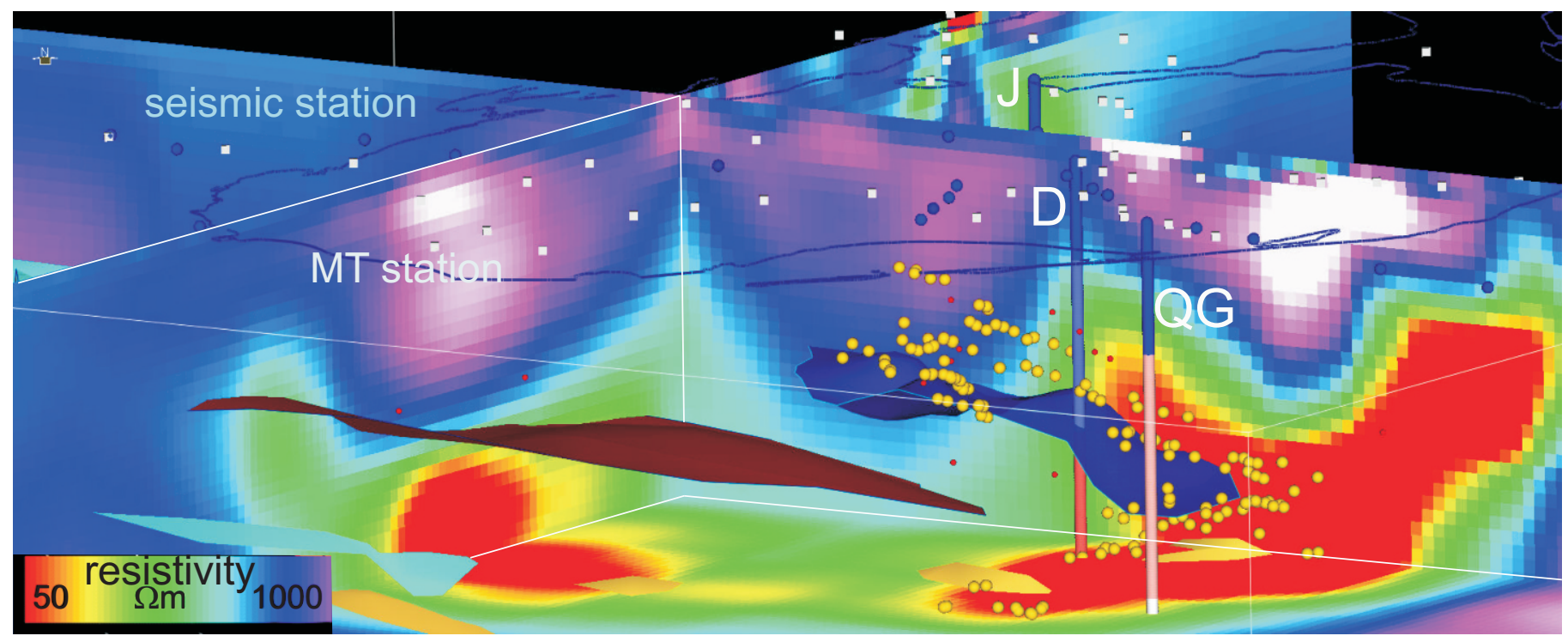

Figure 7. Lithospheric-scale 3-D conductivity model of Slave craton (modified from Snyder et al., 2014). View is from the south. Parts of the Hottah and LDG surfaces are visible at about 100-km depth (see Figure 5). Conductivity appears to be everywhere enhanced by the extensive reducing metasomatism that affected the lithosphere at depths greater than about $100-\mathrm{km}$. In a few locations (e.g., D) equally conductive regions continue upward into the crust, mostly near known kimberlite fields or mineralized zones. Yellow dots, J, D, and GQ are as in Figure 5. 


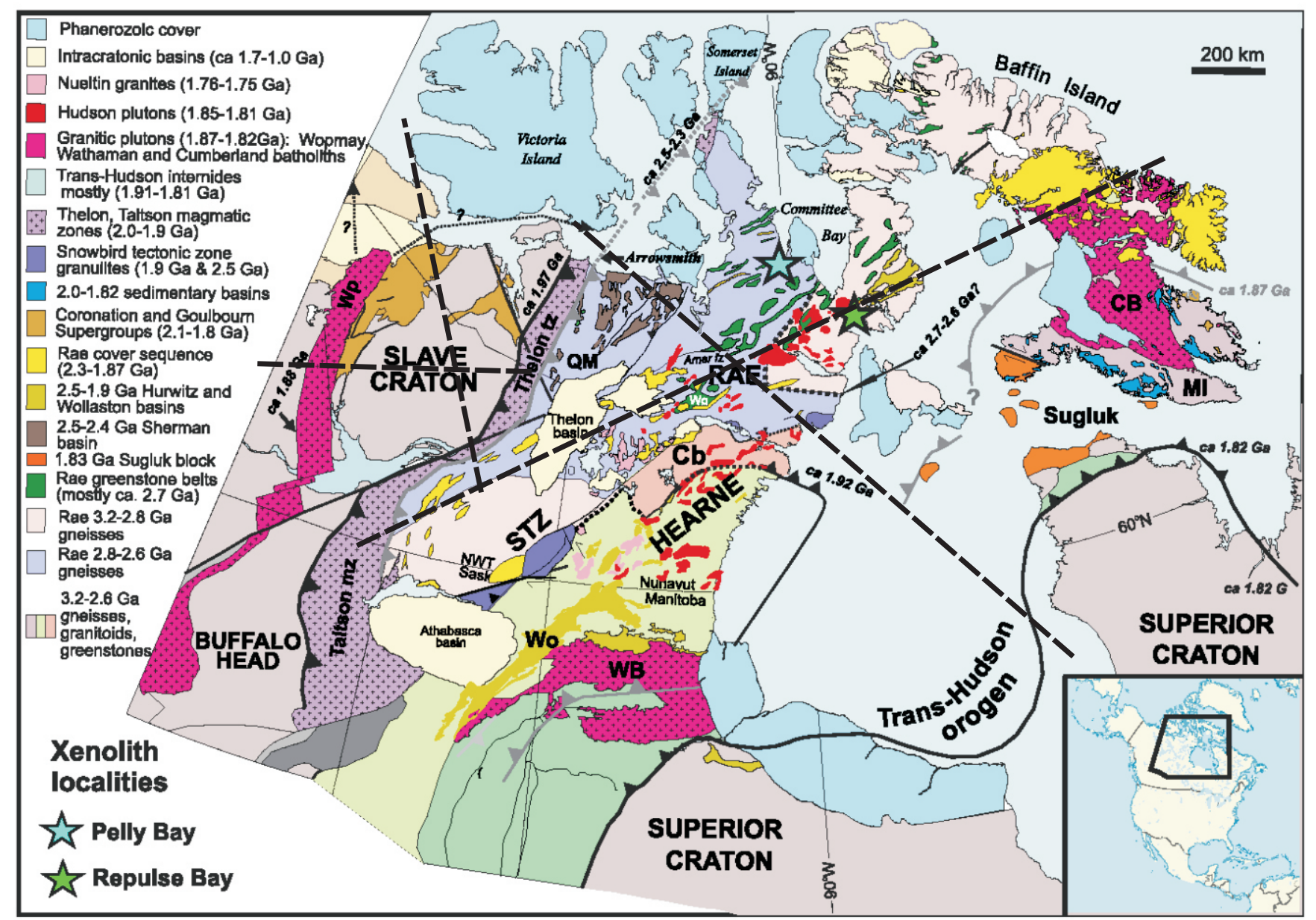

Figure 8. Simplified basement geology map of the Rae craton (modified from Berman et al., 2013). Dashed lines locate sections of Figures 6 and 10. C is the Committee Bay block, QM the Queen block, CB the Cumberland batholith, $\mathrm{Cb}$ the Chesterfield block, $\mathrm{M}$ the Melville Peninsula, MI the MetaIncognita terrane, $\mathrm{Rb}$ the Repulse Bay block, and WB the Wathaman batholith. 


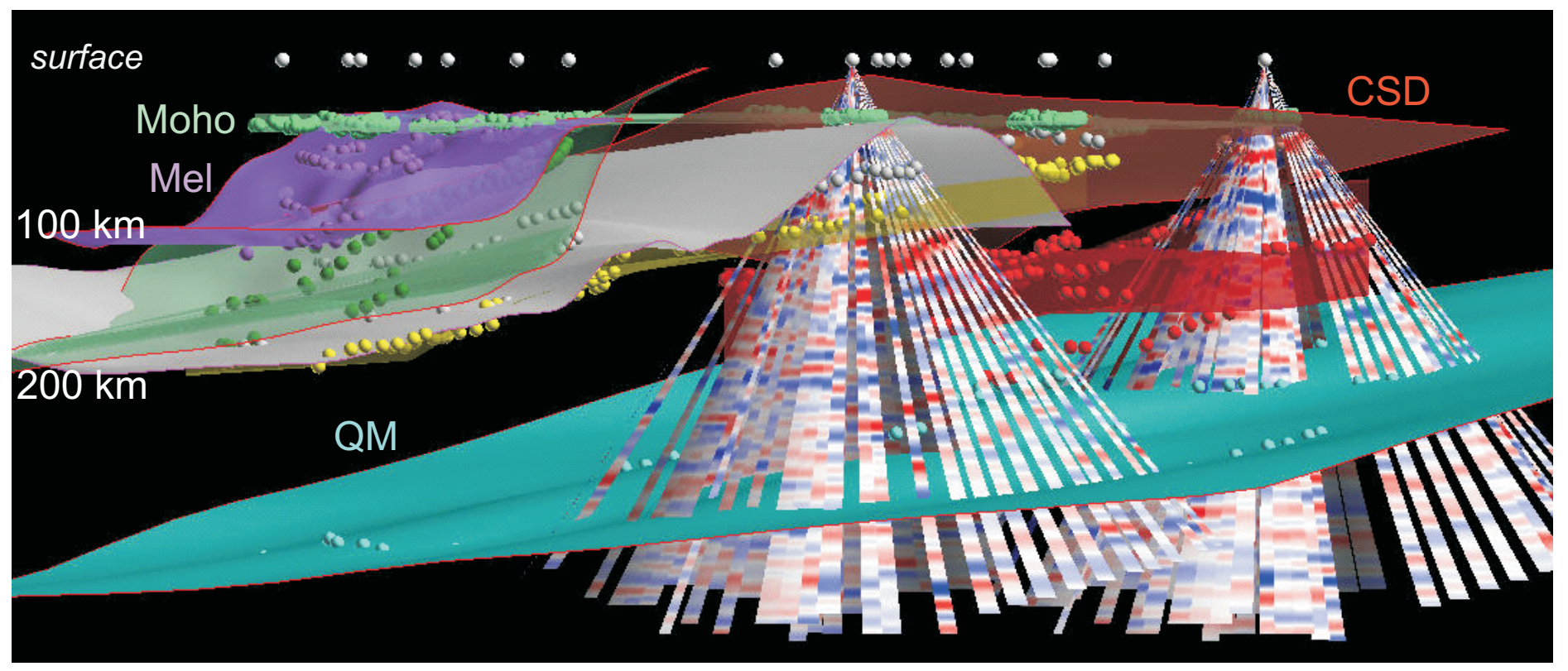

Figure 9. Lithospheric-scale 3-D model of Rae craton structures, viewed from the northwest. Numerous surfaces are determined from seismic discontinuities in Ps receiver functions, most project upward toward major crustal structures such as the Central Structural Domain (CSD) or Chantrey fault (Ch) (Snyder et al., 2015). 


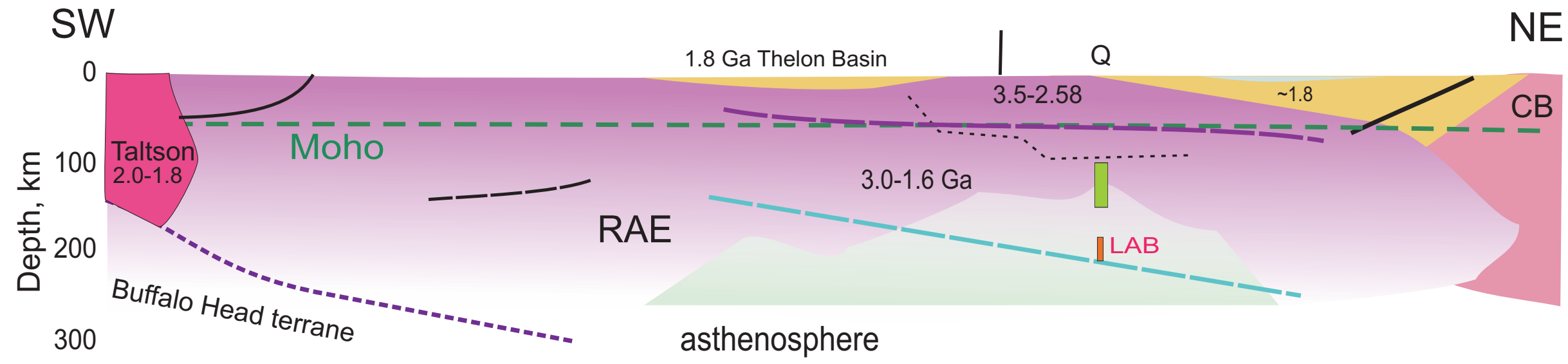

$500 \mathrm{~km}$

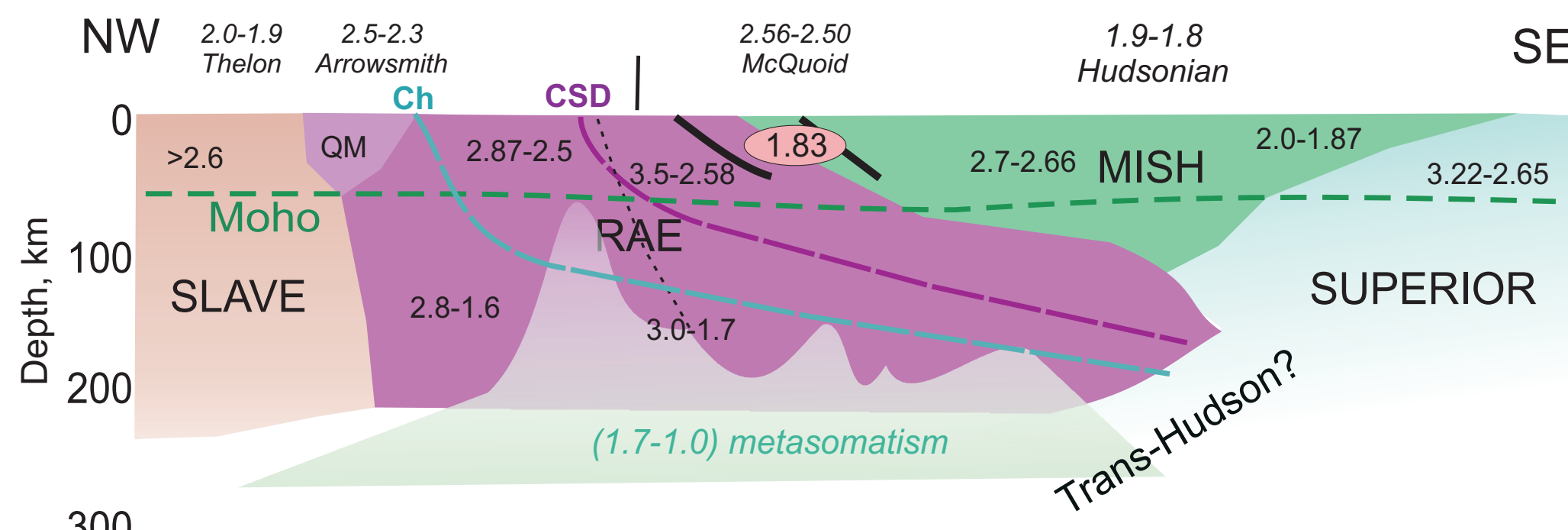

Figure 10. Summary cross sections of the Rae craton. Dashed lines indicate seismic discontinuity surfaces here interpreted as thrust faults that thickened the Rae lithosphere. Solid black lines are faults interpreted from surface structures. Numbers are ages in Ga; italics indicates tectonic events. Late metasomatism at depth is inferred from enhanced conductivity. Ch is the Chantrey fault, CSD is the Central Structural Domain, QM is the Queen Maud block, and CB is the Cumberland batholith. $\mathrm{Q}$ is the Qilaluquaq kimberlite with its xenolith suite rock and lithosphere base (LAB) paleodepths indicated below by rectangles (Liu et al., 2015). 


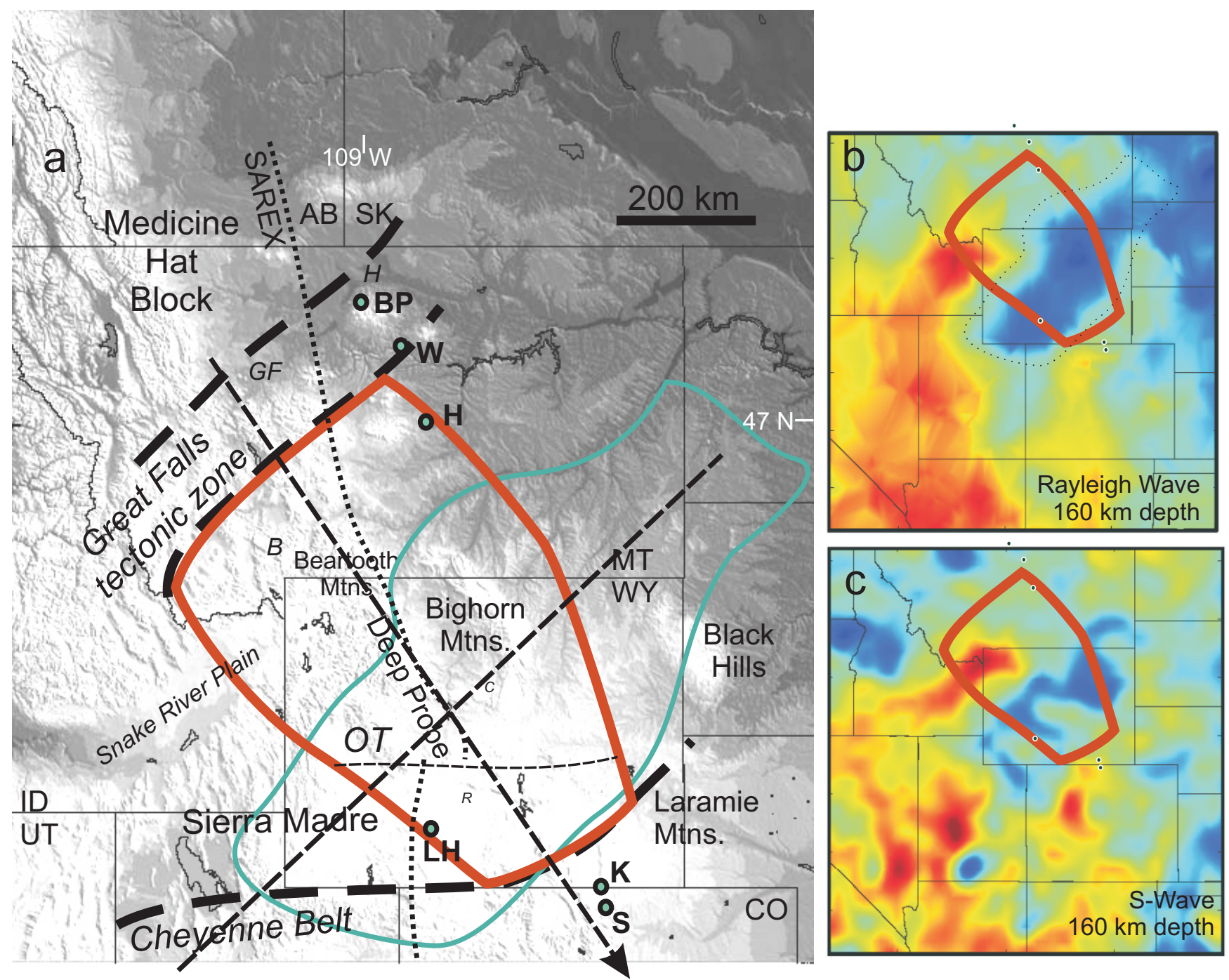

Figure 11. (a) Location map of the Wyoming craton with topography as background. Circles labeled BP, H, W, LH, K, S are xenolith suite locations Bearpaw, Homestead, Williams, Leucite Hills, Kelsey Lake and Sloan, respectively. Heavy dashed lines mark major deformation zones. Lighter dashed line shows location of cross sections in Figure 12. Dotted line marks a regional seismic traverse SAREX/Deep Probe (Gorman et al., 2002). Red line outlines interpreted limits of the Wyoming craton in the crust (Chamberlain, 2015), green line outlines interpreted limits of the Shatsky conjugate part of the underthrust Farallon lithosphere as inferred from relatively greater wavespeeds of surface (b) and S-waves (c) (modified from Humphreys et al., 2015). 


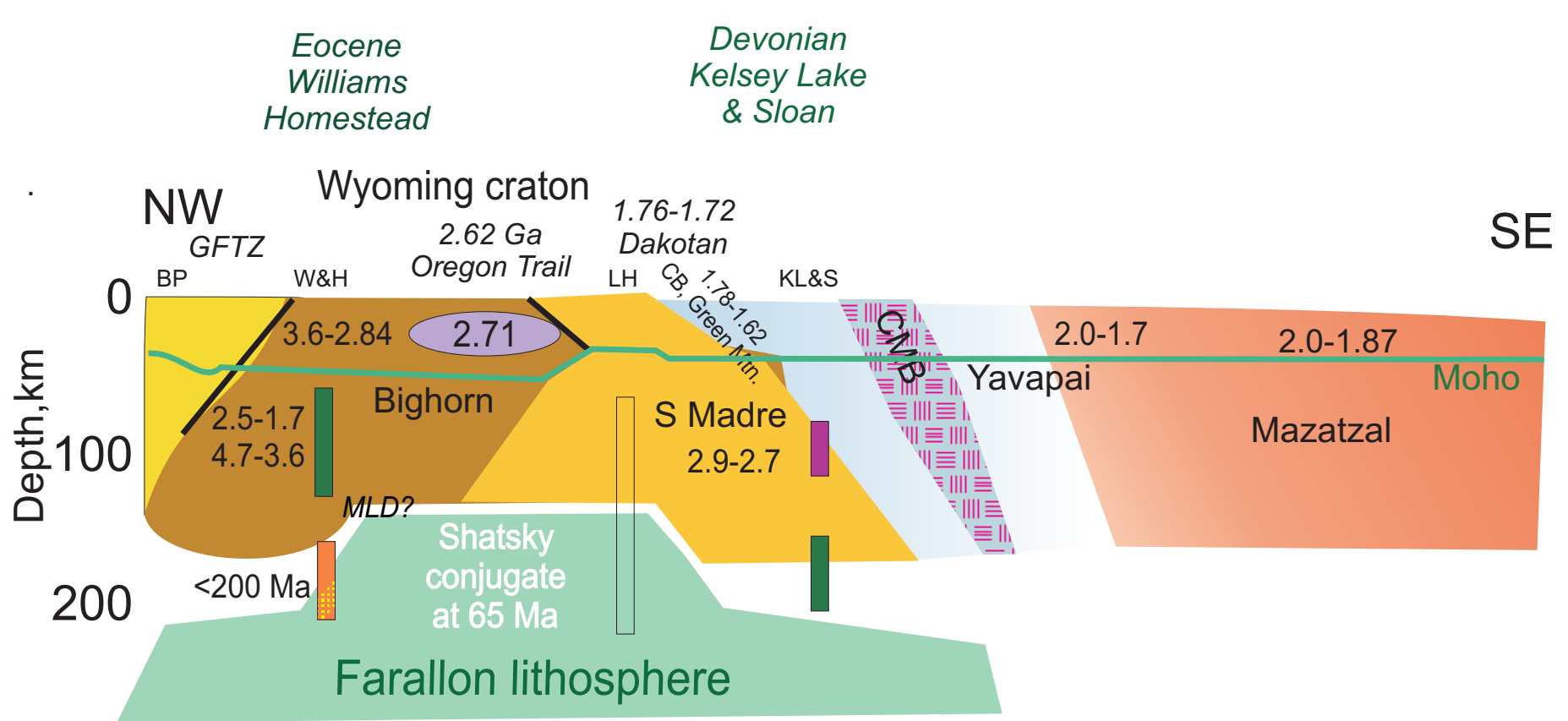

300

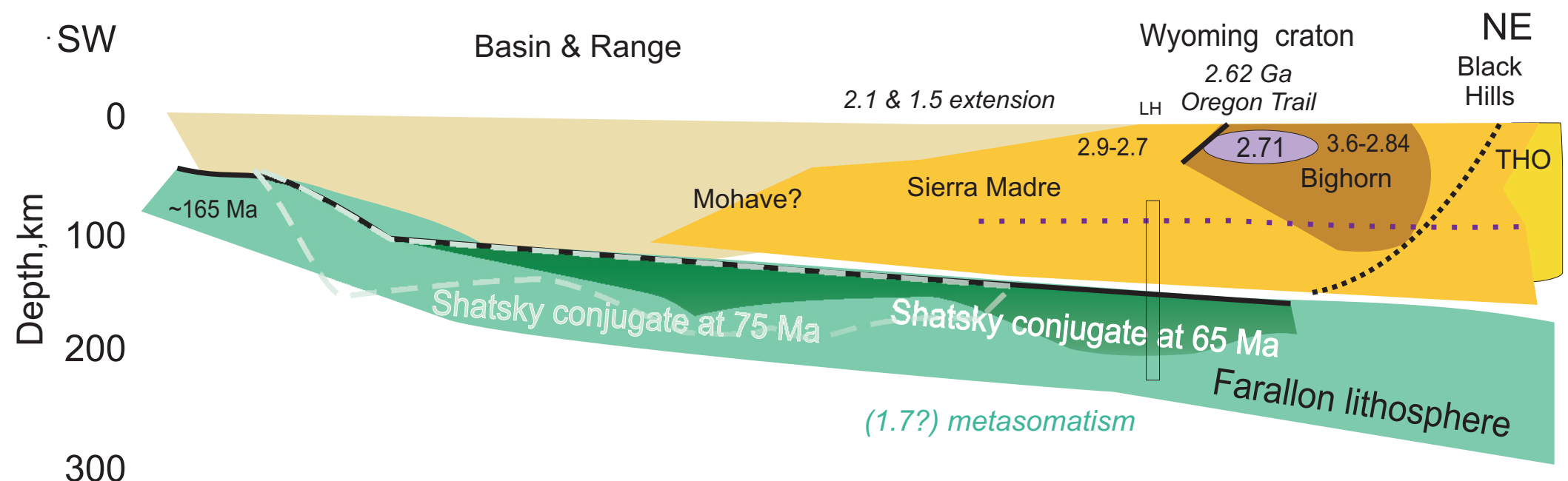

Figure 12. Summary cross sections of the Wyoming craton. Both sections illustrate that a Wyoming craton nucleus (Bighorn block) grew tectonically outward by wedging apart first the accreting Sierra Madre block at $2.62 \mathrm{Ga}$, and then the Green Mountain belt of the Yavapai terrane at $1.75 \mathrm{Ga}$. Numbers are rock ages in Ga (Chamberlain et al., 2003). The vertical columns labelled W\&H and KL\&S are xenolith suite rock types from Williams, Homestead, Kelsey Lake, and Sloan, respectively (Carlson et al., 2004; Schultze et al., 2008). CMB is the Colorado Mineral Belt; THO is the Trans-Hudson Orogen. 

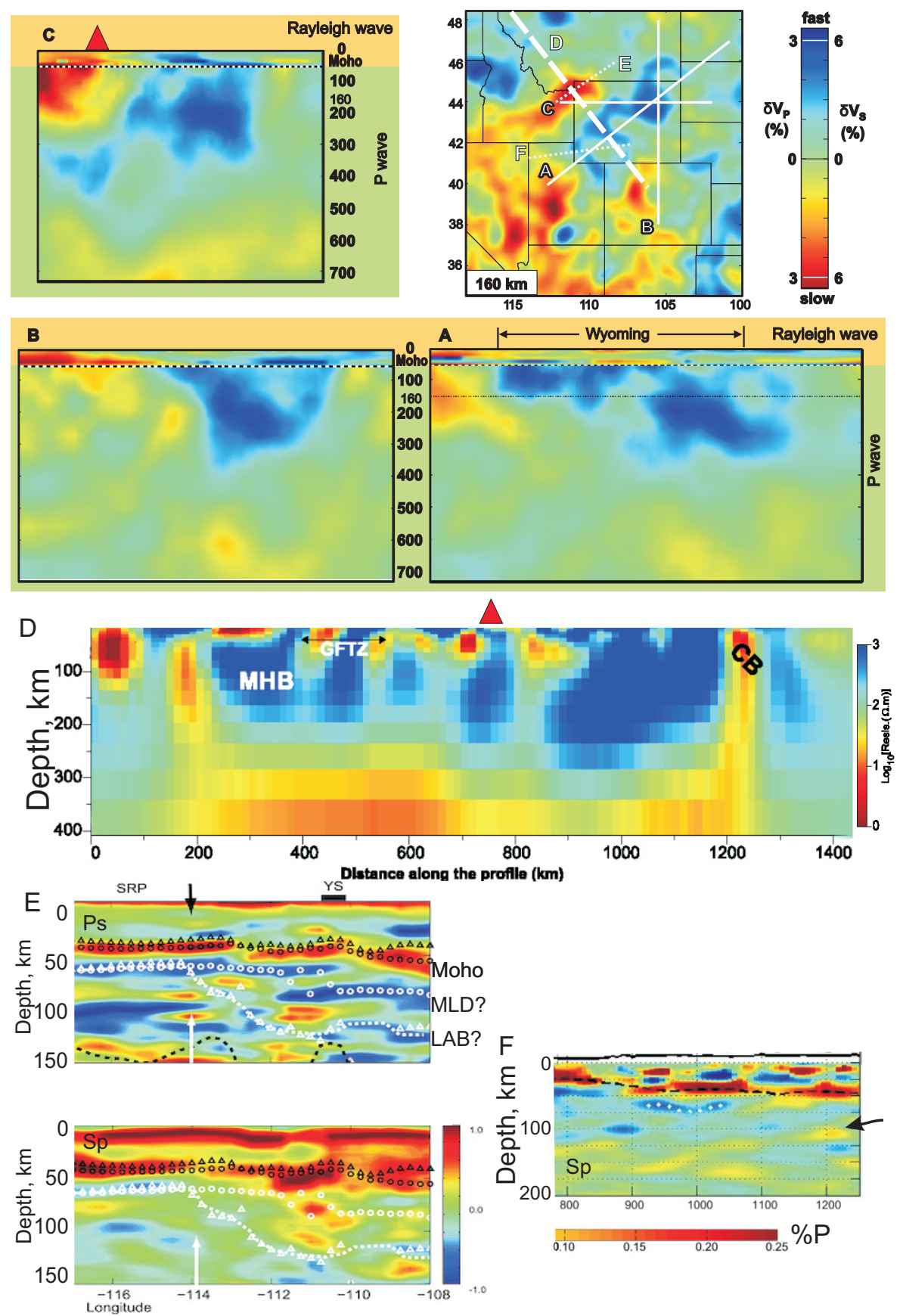

Figure 13. Lithsopheric-scale 3-D seismic tomography (A-C), conductivity (D), and $\mathrm{Sp}$ receiver function models of the Wyoming craton region (modified from Levander and Miller, 2012; Meqhal et al., 2014; Humphreys et al., 2015), presented here as cross sections. Locations are shown on 160-km depth slice of surface wave model. CB is Cheyenne belt, GFTZ is Great Falls tectonic zone, MHB is the Archean Medicine Hat block. Red triangle locates the Yellowstone caldera. 


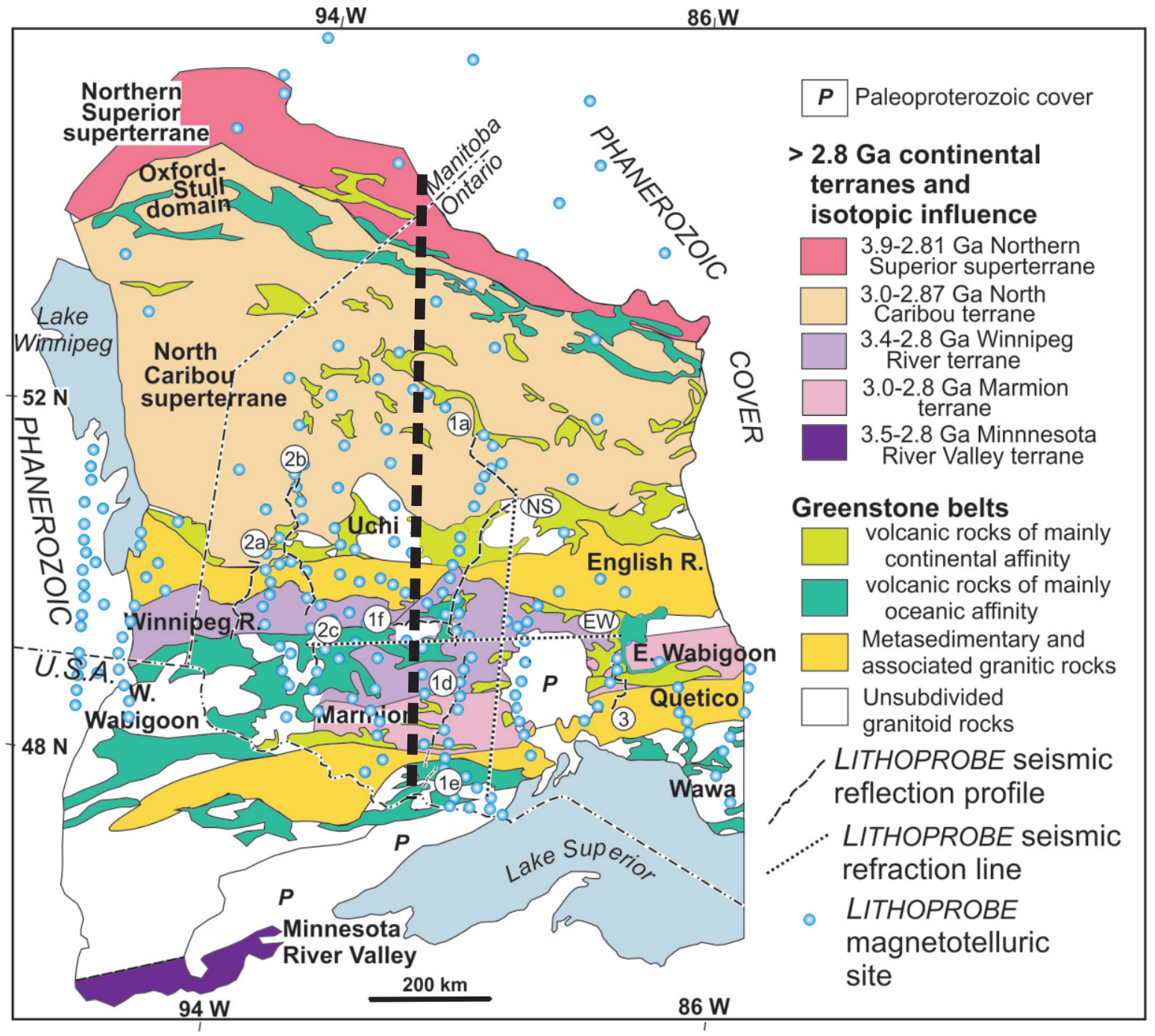

Figure 14. Simplified basement geology map of the western Superior craton (modified from Percival et al., 2006). Dashed lines locate sections of Figure 15. 


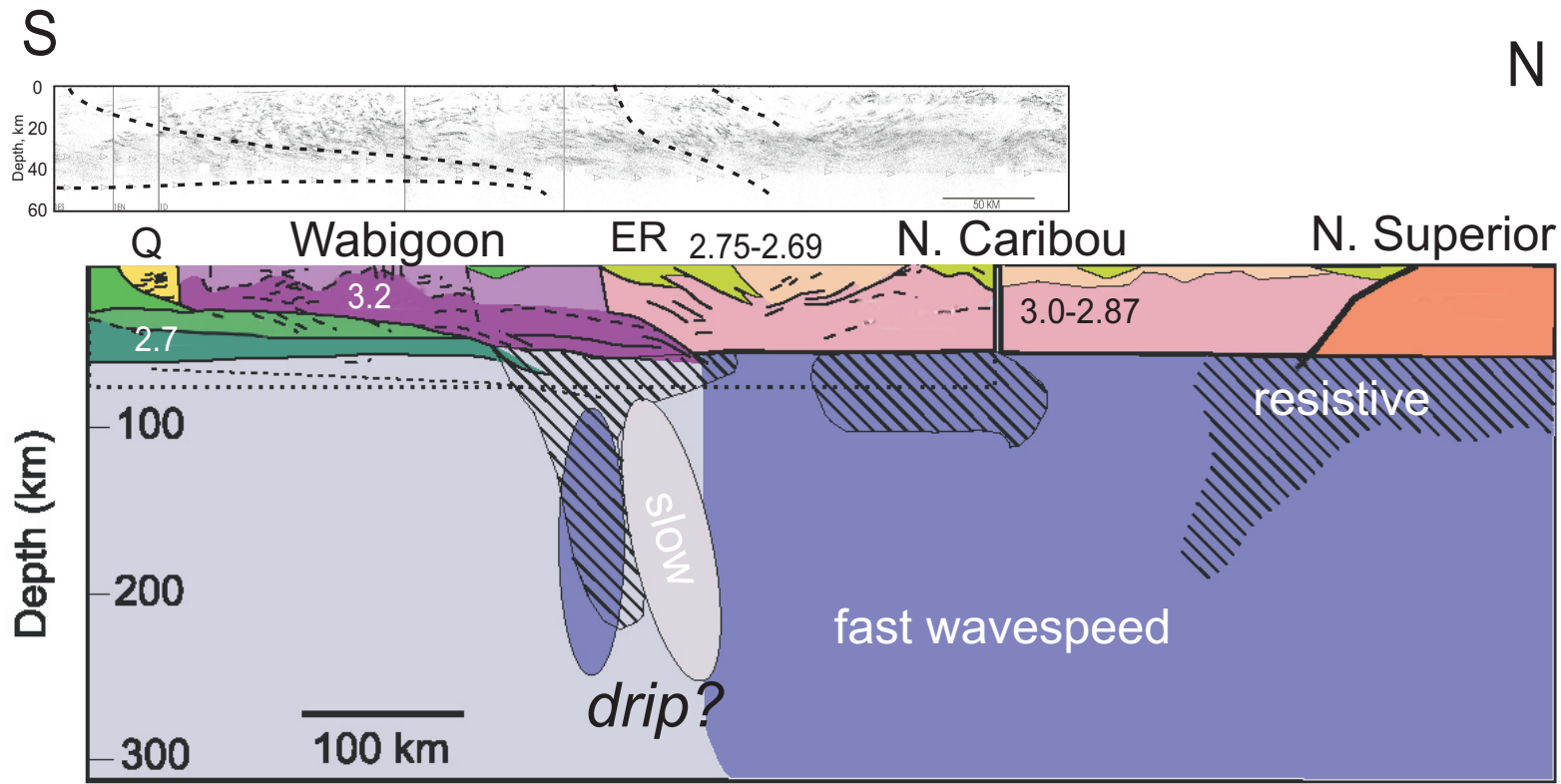

Figure 15. (a) Crustal model of western Superior craton structures as defined by seismic reflections (modified from White et al., 2003). (b) Summary cross section of the western Superior craton. Ages are in Ga (modified from Percival et al., 2006). The most ancient block, the Northern Superior, grew southward by the wedging apart of and subsequent accretion of the North Caribou, Winnipeg River and Wabigoon terranes. ER and Q are the English River and Quentico metasedimentary belts. 